of the evolution of marine sedimentation in the Mediterranean since the latest part of the Miocene is presented.

At times, the last subchapter departs from the realm of objective nonpartisan reporting. We recognize some of the writing as speculative. We will be glad if the tale woven here elicits new avenues of attack on what is to us an intricate and fascinating history of the Mediterranean region.

W.B.F.R.

\title{
47.1. PLIOCENE BIOSTRATIGRAPHY AND CHRONOSTRATIGRAPHY
}

\author{
M. B. Cita, Institute of Paleontology, University of Milano, Milano, Italy
}

\section{INTRODUCTION}

Pliocene sediments have been recovered in forty-two of the more than two hundred cores recovered during Leg 13 of the Deep Sea Drilling Project in the eastern North Atlantic and Mediterranean Sea. Fossiliferous Pliocene sediments were found at Sites 120 (Gorringe Bank), 121 (Alboran Basin), 122 and 123 (Valencia Trough), 124 (Balearic Rise), 127 (Hellenic Trench), 129 (Strabo Trench and Mountains), and 134 (Balearic Abyssal Plain). However, these sites were not continuously cored and the cored intervals were often widely separated. In some cases the material is allochthonous.

The best sections of the Pliocene were those continuously cored at Site 132 in the Tyrrhenian Basin and Site 125 in the Ionian Basin. In fact, at the latter site, the Pliocene interval was cored twice.

In the sedimentary sequence of Sites 132 and 125 the Pliocene is represented by highly calcareous deep-sea pelagic oozes with a low and constant rate of sedimentation. Planktonic foraminifera are by far the most abundant constituent of the sand-sized fraction of the sediment. Such material is ideally suited for biostratigraphic investigations. The thickness of the Pliocene section is 118 meters at Site 132 , where the core recovery exceeds 86 per cent and is about 50 meters at Site $125 \mathrm{~A}$ where the core recovery is unfortunately considerably lower, especially in the Lower Pliocene.

The planktonic foraminiferal zonation proposed here is new. To avoid duplication, reference is made to Chapter 40 , Part II, point 10 , for a discussion of its background and of the criteria used for the selection of the various zonal markers.

The zonation here proposed is fairly close to those recently defined for the Pliocene of Italy (Bertolino et al., 1968), for the Pliocene of Greece (Bizon, 1967), for the Pliocene of Italy and other Mediterranean regions (Cati et al., 1968) and can be correlated with them (see further below). The most important difference is that in the zonation here proposed for the deep-sea Mediterranean sediments we do not use as zonal markers either Globorotalia aemiliana (or $G$. hirsuta aemiliana, or $G$. crassaformis aemiliana or $G$. crotonensis), or $G$. crassaformis. Both taxa have been recorded in the DSDP cores, but their occurrence, especially that of $G$. crassaformis cum var., appears strongly controlled by some ecological factors (see range charts in Chapters 7 and 13).

Globorotalia crassaformis is a mesopelagic species, living in the present seas and known in fossil sediments as old as early Pliocene (Miocene according to Blow, 1969).

The frequency curve of $G$. crassaformis (group), based on thirty samples investigated from the Pliocene section continuously cored at Site 125 , does not show a correlation with the inferred climatic curve based on the occurrence of a restricted number of epipelagic, temperature-sensitive species of Globigerinoides, whose distribution in the present seas is limited to the tropical or subtropical areas (see Cita and Ciaranfi, 1971, and Chapter 47.3). Therefore, the factor which controls the very irregular abundance of $G$. crassaformis is not the temperature of superficial waters in the photic zone, but possibly changes in the structure of the permanent thermocline, or other ecological factors.

Although ten months have been dedicated to the investigation of the Pliocene sections under discussion, the present study is still preliminary in some aspects. Shortage of space and time have prevented a thorough documentation of the foraminiferal faunas.

The taxonomy of some groups, including the Globorotalia crassaformis group, is provisional. No taxonomical notes will be included here, with the exception of the Globorotalia margaritae group, on which statistically oriented investigations have been done (see Section on statistical investigations on this group). We had to describe two new taxa, since one of them has been used as zonal marker. Two more new taxa recorded in the Mediterranean DSDP cores will be published elsewhere, as will further paleontological investigations.

In the present chapter only the aspects of Pliocene foraminiferal biostratigraphy considered of interest for the project will be examined. 


\section{THE MIOCENE/PLIOCENE BOUNDARY}

This boundary can be recognized within a single core section at Sites 134 (Balearic Abyssal Plain), 132 (Tyrrhenian Rise), and 125A (Mediterranean Ridge in the Ionian Basin). In fact, the contact is so sharp that one can put a fingernail on the visible disconformity that it represents. ${ }^{1}$ Figures 1, 2 and 3 illustrate Sections 134-7-5, 132-21-2 and $125 \mathrm{~A}-6-1$ where the boundary is present; the figures are also accompanied by some biostratigraphical notes concerning the intervals investigated paleontologically.

The Miocene/Pliocene boundary coincides with the sharp sedimentary break that occurs between the evaporitic sequence below and the pelagic sediments above.

At two more sites, namely, Site 122 in the Valencia Trough and Site 124 on the Balearic Rise, south of Mallorca, the boundary is not present within a single core. It occurs somewhere in the uncored interval between two successive cores which are so different both in lithology and in fossil content, and yet so close to one another, that we can consider also in these cases that the boundary represents a dramatic change in environmental conditions.

The Pliocene pelagic oozes which overlie the Miocene evaporites correspond both in lithology and fossil content to the "Trubi" formation of Sicily, and the evaporitepelagite contact corresponds to what may be seen in Sicily, where the "Trubi" marls directly overlie the "formazione gessoso-solfifera." 2

The high-resolution biostratigraphy developed for the Pliocene indicates that the pelagic sediment immediately overlying the late Miocene (Messinian) evaporites is not of the same age in the three different basins.

The basal layer of Pliocene ooze at Site 132 in the Tyrrhenian Basin belongs to the Sphaeroidinellopsis Acmezone. The basal layer at Site 134 in the Balearic Basin belongs to the Globorotalia margaritae margaritae Lineagezone, and that a Site $125 \mathrm{~A}$ in the Ionian Basin belongs to the Globorotalia margaritae evoluta Lineage-zone.

This observation cannot be easily explained, and was of concern to the shipboard scientists, since the deluge model which fits so much of the other data and which is attractive as a working hypothesis (see Chapter 43) would lead us to conclude that pelagic ooze should have started to accumulate in each of the basins simultaneously.

Two explanations, which are difficult to evaluate, can be offered to explain how the first ooze which was permanently preserved above the evaporites can be diachronous.

1) Vigorous submarine erosion in the early Pliocene could have prevented deposition, or could have eroded away previous loose pelagic deposits down to a firm substratum (e.g., to lithified dolomite in Core 6 of Site $125 \mathrm{~A}$; see Chapter 6 for documentation of just such a deep-sea erosion/nondeposition at Site 124).

\footnotetext{
${ }^{1}$ Details of the contact in all three basins are depicted in the color frontispiece of this volume.

${ }^{2}$ Ogniben (1969, 653-654) considers an "abnormal transgression" that which leads to normal marine conditions in the evaporitic Messinian basins. "Si deve considerare l'ipotesi che questa trasgressione sia dovuta al risalire delle acque da livelli negativi al livello degli oceani, con velocità verosimilmente maggiore di quella di un fenomeno epirogenetico."
}

2) Subsequent tectonic movements on the sea bed caused by volume change, solution, or cavern collapse in the underlying evaporite could lead to slumping or fault displacement.

In other words, although the event (Pliocene transgression or flood of the desiccated Mediterranean basin) was isochronous everywhere within the basin, the oldest sediments preserved might not necessarily be isochronous at all locations, due to more or less local factors.

As base of the Pliocene we therefore take the base of the section at which all the foraminiferal zones and all the nannofossil zones are present, namely Core DSDP 132-21-2 (see text Figure 2).

\section{THE PLIOCENE/PLEISTOCENE BOUNDARY}

The Pliocene/Pleistocene boundary (Figure 4) was cored at Sites 122 and 123 (Valencia Trough), 134E (Balearic Basin and Sardinia slope, respectively), 132 (Tyrrhenian Rise) and 125 (Mediterranean Ridge in the Ionian Basin). At other sites, particularly Sites 121 (Alboran Basin) and 124 (Balearic Rise), this boundary lies in an uncored interval between two successive cores referable to the Pleistocene and to the Pliocene respectively.

At Sites 122 and 123, the Quaternary sediments represent channel fill; an erosional surface separates them from the underlying Pliocene sediments, with an important gap in sedimentation (see Chapter 40.2, Part II, point 8). A hiatus, with hard-ground, has been recorded also at the Pliocene/Pleistocene boundary at Site 134, at the eastern edge of the Balearic Abyssal Plain (Sidewall Core 1, 134E; see Chapter 40, Plates 2 and 3.

Thus, at all these western Mediterranean sites the biostratigraphic boundary falls at a marked discontinuity. However, at both sites continuously cored from the central (132) and eastern (125) Mediterranean basins the boundary lies in an entirely uninterrupted marine succession of uniform lithology.

The boundary under discussion is defined by the (massive) extinction horizon of Discoaster brouweri, a biostratigraphic event which is clearly recognizable in all the Mediterranean drilling sites.

The Pliocene/Pleistocene boundary is much less clear in terms of foraminiferal biostratigraphy (Berggren, 1971). In fact, no extinction horizon or first occurrence can be used as a datum level.

Globigerina pachyderma, used sometimes as marker species in the Mediterranean, occurs below as well as above the extinction horizon of Discoaster brouweri. Its ratio of left to right coiling (used as the criterion for recognizing the beginning of the Quaternary by Bertolino et al., 1968; Cati et al., 1968) cannot be used either, since G. pachyderma, as recorded in Mediterranean DSDP cores, is right coiling throughout, with the exception of some of the coldest intervals recorded in the glacial Pleistocene.

The first appearance of Globorotalia truncatulinoides, evolving from $G$. tosaensis, is considered by Hays and Berggren (1971) to be the most reliable biostratigraphic event for recognizing the Plio/Pleistocene boundary. However, we could recognize this event only once in our cores, namely in Core 125-4 (Mediterranean Ridge), slightly below the extinction horizon of Discoaster brouweri. At the 


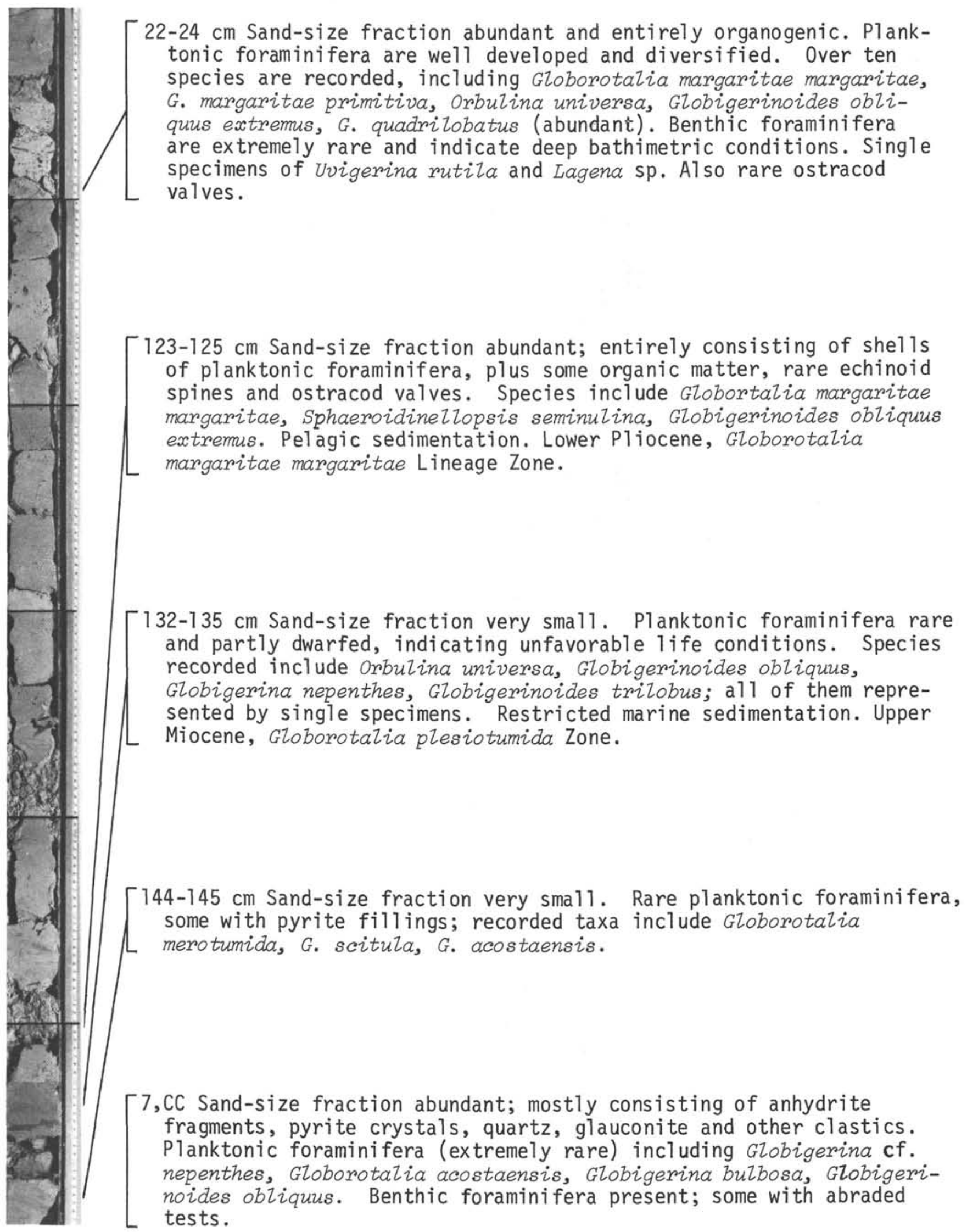

Figure 1. The Miocene/Pliocene boundary at Site 134 (Balearic Basin). Photograph of Core 134-7-5 and biostratigraphical comments on the samples investigated. 


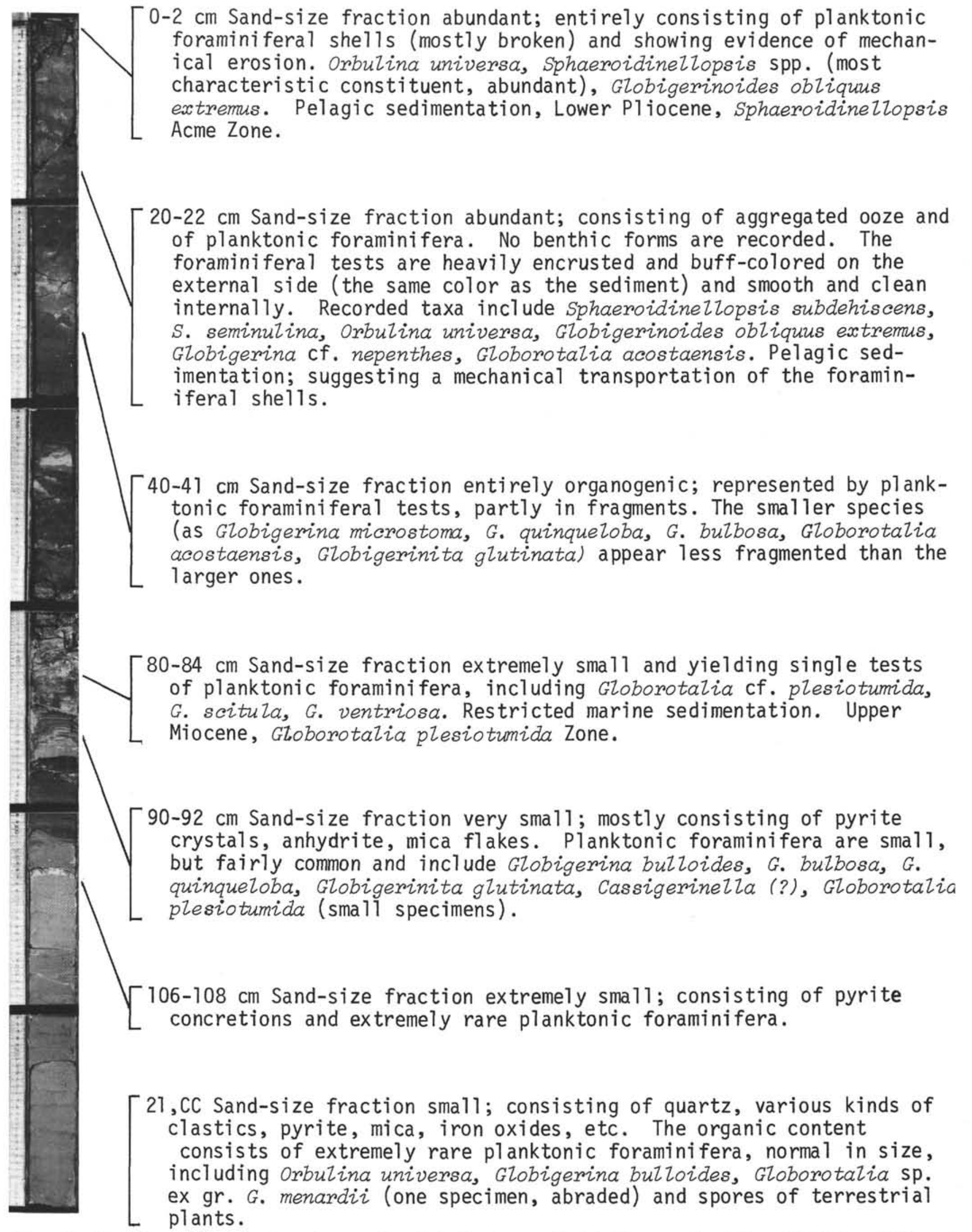

Figure 2. The Miocene/Pliocene boundary at Site 132 (Tyrrhenian Basin). Photogranh of Core 132-21-2 and biostratigraphical comments on the samples investigated. 


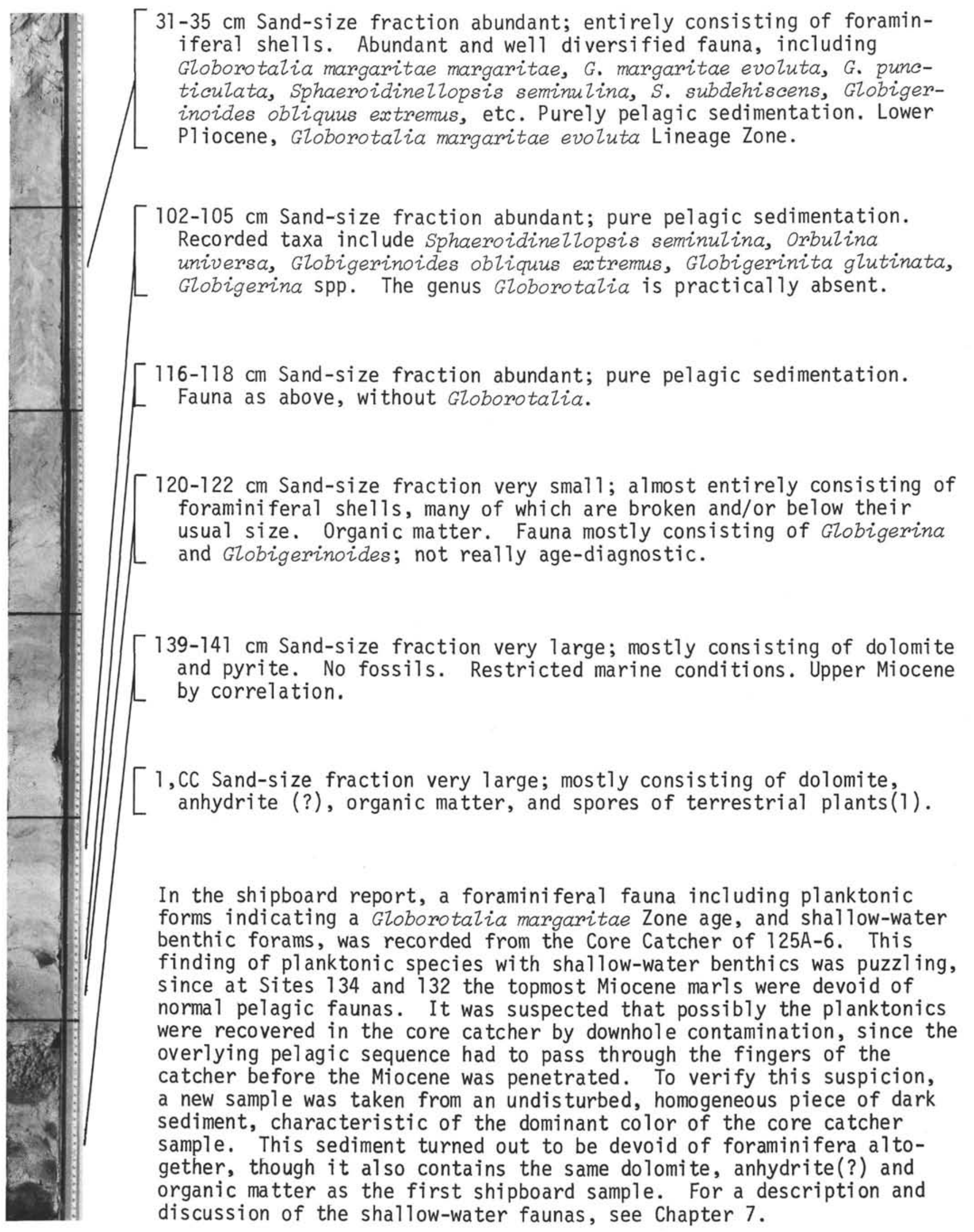

Figure 3. The Miocene/Pliocene boundary at Site 125A (Ionian Basin). Photograph of Core 125A-6-1 and biostratigraphical comments on the samples investigated. 
M. B. CITA

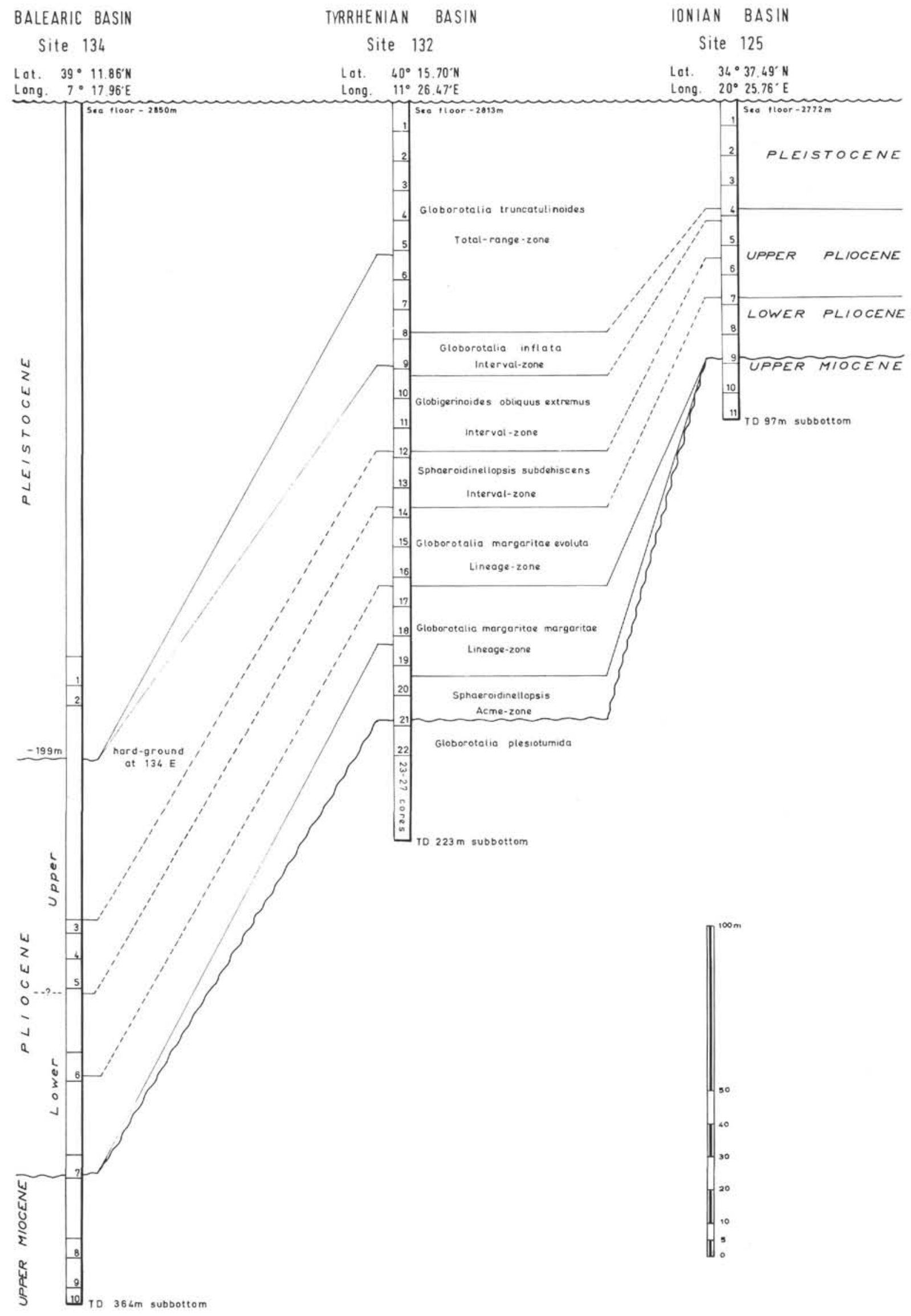

Figure 4. Pliocene boundaries, foraminiferal zones and biostratigraphic correlations in the Balearic, Tyrrhenian and Ionian basins. 
remaining sites, $G$. truncatulinoides appears much higher in the succession, and $G$. tosaensis is extremely rare or absent. This demonstrates that both species are probably ecologically controlled and cannot be used as reliable zonal markers in the Mediterranean.

The almost perfect coincidence between the Globorotalia truncatulinoides datum and the Discoaster extinction datum in DSDP Core $125-4$, however, allows us to check the reliability of the latter datum in order to identify the Pliocene/Pleistocene boundary in the Mediterranean.

Hyalinea baltica, the first occurrence of which in the Le Castella Section, Calabria, has been taken as marker point for the Plio/Pleistocene boundary (INQUA Congress, 1965). It was found only at two of the Mediterranean sites (121 and 122). At the latter, it is surely displaced in a channel fill deposit; in the former, our shallowest drilling site, it is possibly in place.

$H$. baltica was never recorded in the 220 samples from the Tyrrhenian Basin, nor in the 185 samples from the Ionian Basin, which were investigated in detail from continuously cored successions (see Chapter 46). Obviously, this benthic species, which lives in the Mediterranean at depths ranging from 60 to 1000 meters, cannot be used as a biostratigraphic indicator in pelagic deep-sea deposits.

\section{STATISTICAL INVESTIGATIONS ON THE GLOBOROTALIA MARGARITAE GROUP}

\section{Introduction}

All that lies between the Discoaster extinction level and the uppermost layer of the evaporites is referred to as the Pliocene. In the cores recovered from this interval, we noted an important biostratigraphic event, namely, the extinction horizon of Globorotalia margaritae.

Extinction levels are optimal in the biostratigraphy of cored sequences if they can be shown independently to be isochronous. This is so because drilling techniques can mix sediments downhole, thus potentially confusing first occurrences, but drilling techniques cannot mix the sediment upwards. Secondly, Hays et al. (1969) have demonstrated that the extinction level of Globorotalia margaritae occurs at the Gilbert/Gauss paleomagnetic boundary (3.32 my) in piston cores from the Pacific and Indian oceans.

Chapter 47.2 will show that the Globorotalia margaritae extinction level at Site 132 also occurs at this boundary. Because the Globorotalia margaritae extinction level lies about midway between the Discoaster brouweri extinction level and the evaporites, we have, in the hope of obtaining other biostratigraphic criteria to further subdivide the lower part of the Pliocene, examined the Globorotalia margaritae group in all of our cores.

One such anticipated criterion was a distinct morphologic evolution in the Globorotalia margaritae group which could be considered and demonstrated to be isochronous. Globorotalia margaritae is the most conspicuous constituent of the foraminiferal assemblages of the Lower Pliocene of deep-sea Mediterranean deposits. It is the only keeled Globorotalia and is present in a majority of the samples, often with hundreds of specimens that show considerable morphological variation.

From the very beginning of our investigations on board the Glomar Challenger, we observed a certain evolution in the populations referable to Globorotalia margaritae (broadly interpreted). Where we had samples from more than one core from the same drilling site which could be assigned to the Globorotalia margaritae Zone, the most obvious evolutionary trends that we could perceive were an increase in size and the acquisition of a subcircular instead of an elongate equatorial outline, resulting from a different (slower) growth pattern. Other, less obvious changes apparently concern the height of the spire and the peripheral characters.

At Site 132, Globorotalia margaritae has a total stratigraphic range of 50 meters. This section was therefore ideally suited to statistically oriented foraminiferal investigations.

\section{Stratigraphic Importance of Globorotalia margaritae}

Globorotalia margaritae Bolli and Bermudez was originally described from the Miocene of Venezuela. The Miocene age was based on the molluscan fauna of the Cubagua Formation (Cubagua Island, Peninsula Araya, Venezuela). In the world-wide zonation of Bolli (1966a) the Globorotalia margaritae Zone, defined as a total-range zone, is entirely confined to the Miocene, being the penultimate Miocene biozone. However, the age determination for the Cubagua formation should be considered doubtful on the basis of present knowledge.

The type locality of a part of the Pliocene biozonation of Bolli (1966a) is Margarita Island off Venezuela. G. margaritae has been subsequently recorded in Java (Bolli, 1966b), in the equatorial Pacific (Parker, 1967), and at many other localities. In the Mediterranean area, where it is apparently more common than in the Caribbean and Gulf of Mexico, this species was often recorded as Globorotalia hirsuta (d'Orbigny). At the congress on Mediterranean Neogene Stratigraphy held in Bologna (1967), it became apparent in discussions among micropaleontologists of various schools that Globorotalia hirsuta of the Italian workers (see for instance, AGIP Mineraria, 1957; Ruggeri, 1960; Colalongo and Sartoni, 1967; Iaccarino, 1967; Barbieri, 1967; d'Onofrio, 1968; Dondi and Papetti, 1968) is identical to Globorotalia margaritae Bolli and Bermudez (1965).

Globorotalia hirsuta (as interpreted by the Italian workers cited) is considered a typical Lower Pliocene marker. However, it has been at times recorded from pre-Pliocene sediments (see AGIP Mineraria, 1957 (Tortonian); d'Onofrio, 1964 (Messinian); Dondi and Papetti, 1968 (Tortonian and Messinian)). ${ }^{3}$ Colalongo (1970) recorded and illustrated Globorotalia margaritae from level 105 of the Messinian neostratotype ("Marne argillose superiori"). The figured specimen apparently may be identified with our Globorotalia margaritae primitiva. Having actually seen the locality of level 105 of the neostratotype Messinian, as well as its paleontological content, the author doubts that Globorotalia margaritae, as well as the Cyprideis pannonica and contains Ammonia beccarii tepida, thus indicating ipohaline conditions.

Sphaeroidinellopsis present in this level, are autochthonous constituents of the assemblage, which is extremely rich in

\footnotetext{
${ }^{3}$ The aforementioned authors pointed out that the pre-Pliocene specimens are rare and smaller than the Pliocene ones.
} 
In the new Pliocene zonation by Bolli (1970), based on DSDP cores from Leg 4 in the Central Atlantic and Caribbean, the Globorotalia margaritae Zone is considered to be entirely Pliocene, its lower boundary coinciding with the Miocene/Pliocene boundary. Once again, this age assignment is conventional and not related to any defined stratotype section.

In our new deep-sea Mediterranean zonation, we use a Globorotalia margaritae Total-range zone, a kind of super zone to which belong our lower three zones plus an undefined interval of late Miocene age. Because of the quite abnormal ecologic conditions during the late Miocene, the Mediterranean is not a suitable area to study the first evolution of this species.

The extinction of the Globorotalia margaritae group, which is extremely abundant and highly evolute, is quite sudden in all the drilling sites and consistently occurs within the latest part of the Discoaster asymmetricus Zone. The top of this zone is defined by the extinction horizon of Ceratolithus tricorniculatus, according to the zonation by Martini and Worsley (1970). Thus, the extinction horizons of $C$. tricorniculatus and $G$. margaritae nearly coincide, the former being slightly higher than the latter.

\section{Procedures Followed}

For the statistical investigation of Globorotalia margaritae, one sample from each core of Site 132 belonging to the Globorotalia margaritae zones ${ }^{4}$ was used: $132-14$, CC; $132-15-2,35 \mathrm{~cm} ; 132-16-3,35 \mathrm{~cm} ; 132-17-4,35 \mathrm{~cm}$; $132-18-4,35 \mathrm{~cm}$; and $132-19-1,35 \mathrm{~cm}$. The distance between sample levels ranges from 4.5 to 10.5 meters. The corresponding time interval (with a sedimentation rate approaching $2.8 \mathrm{~cm} / 10^{3} \mathrm{y}$ ) ranges from 160,000 to about 350,000 , averaging 300,000 .

From each level we extracted 100 specimens, at random, of $G$. margaritae s.l. The specimens are fairly variable in size but have some significant features in common, including: (a) general shape of the test elongated to subrounded, (b) more or less asymmetrically biconvex test, (c) more or less flattened, (d) fairly rapid growth of the chambers, especially in the last formed whorl, (e) subacute to faintly keeled periphery, (f) thin, uniformly perforated wall, (g) extended hispidity of the surface in the early ontogenetic stages, (h) petaloid chambers, (i) more or less lobulated periphery, (j) small and slightly depressed umbilicus, (k) radial and slightly depressed intercameral sutures on the umbilical side, (1) gently curved and more or less limbated intercameral sutures on the spiral side visible only in the last whorl, (m) slit-like umbilical-extraumbilical aperture, partly covered by a more or less extended lip, and (n) coiling dominantly left (95\% of 600 measured specimens). A number of variable characteristics are apparent from this list, yet only a small number can be measured.

A limited number of statistically oriented studies of planktonic foraminifera have been published to date (e.g., Scott, 1968; Gradstein, 1971; Lindenberg, 1969. The studies indicate that it is as yet unclear which parameters of foraminiferal variability are significant from an evolutionary or taxonomical standpoint.

\footnotetext{
${ }^{4}$ Core 20 has been disregarded, because $G$. margaritae is present only in Section 2 with a limited number of specimens.
}

In the present study, the continuous and discontinuous variables measured on the test of Globorotalia margaritae are indicated below.

Continuous Variables: (a) equatorial diameter passing through the last formed chamber (A-A' in Figure 5, (b) equatorial diameter perpendicular to $A-A^{\prime}$ (B-B' in Figure 5, (c) width of the last-formed chamber (C-C' in Figure 5, (d) axial diameter (D- $\mathrm{D}^{\prime}$ in Figure 5). The measurements were made on a binocular microscope, using a magnification of $100 \times$.

Discontinuous Variables: (e) characters concerning the axial periphery. Five frequency classes were distinguished (Figure 6), ranging from a subacute periphery to a keeled periphery with a distinctly imperforate keel on three or more chambers; (f) characters concerning the equatorial periphery. Three frequency classes were distinguished: slightly lobulated, lobulated and strongly lobulated; (g) characters concerning the surface of the three frequency classes: (very hispid, hispid, moderately hispid); (h) number of chambers in the last-formed whorl: four frequency classes (from $4-1 / 2$ to 6 chambers); (i) coiling direction (two frequency classes: left and right).

The elaboration of these measures is in progress and the results will be published later. Figure 6 illustrates the histograms concerning characters (d) and (e) of the preceding list. A distinct change is observed in both of them, especially in the axial diameter, between the populations investigated from Cores 16 and 17 ; it is in this interval that

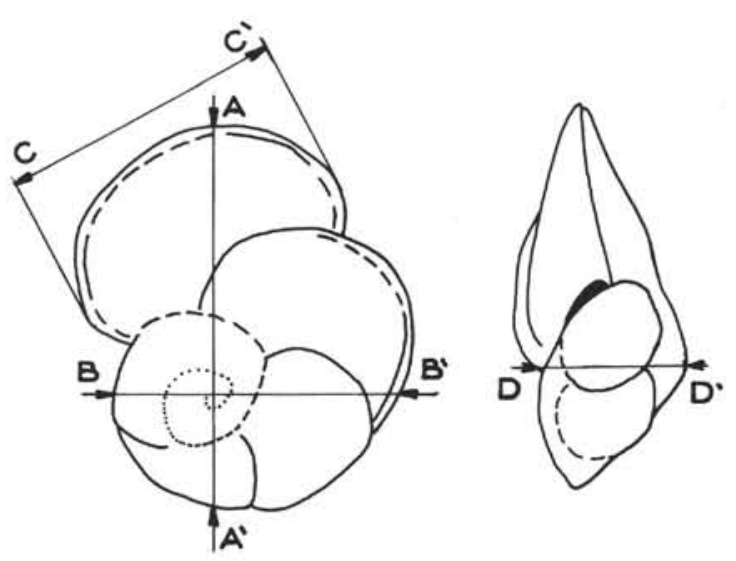

Figure 5. Continuous variables, as measured on Globorotalia margaritae (for further explanations, see text). $A-A^{\prime}=$ equatorial diameter (maximum) passing through the last-formed chamber, $B-B^{\prime}=$ equatorial diameter perpendicular to $A-A^{\prime}, \mathrm{C}-\mathrm{C}^{\prime}=$ width of the lastformed chamber, and $D-D^{\prime}=$ axial diameter. 


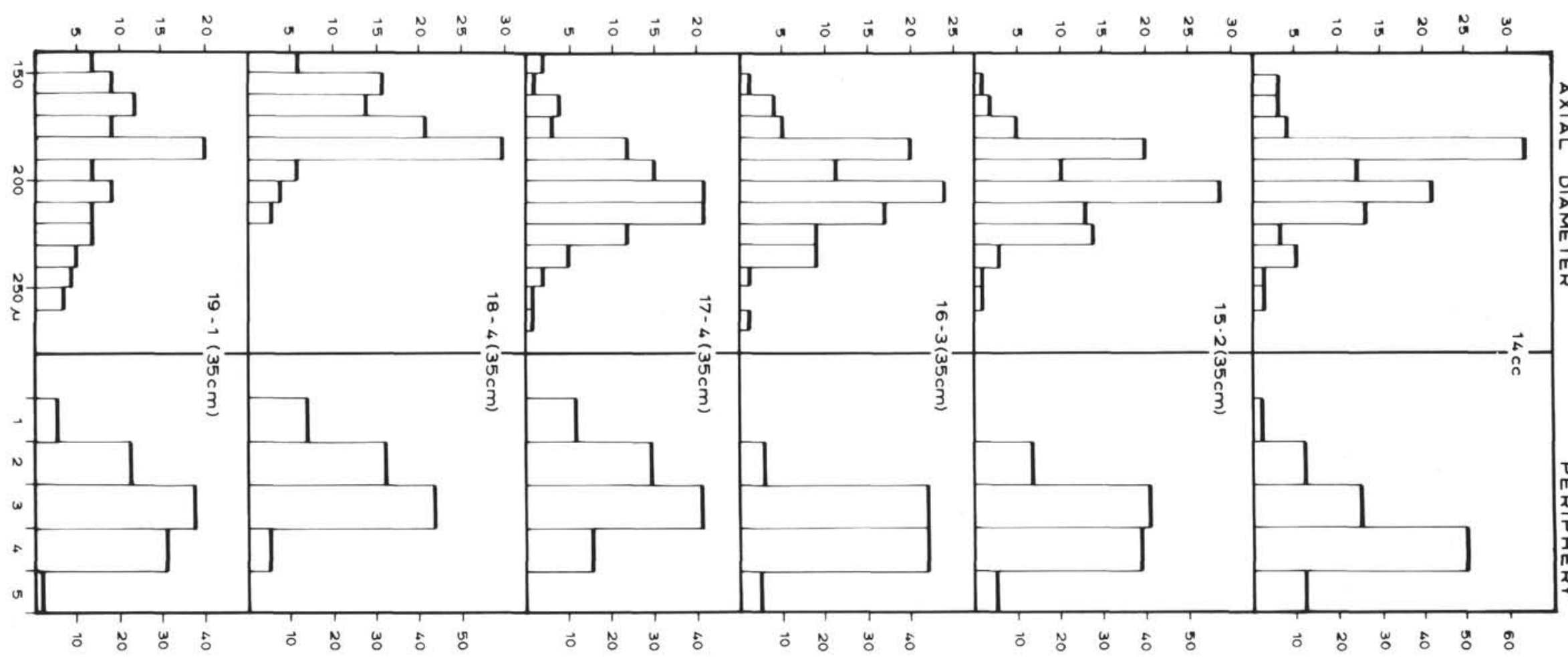

Figure 6. Histograms showing changes in the axial diameter (left) and in the periphery (right) observed in 100 random specimens of Globorotalia margaritae (group) from six levels investigated at Site 132 (Lower Pliocene of the Tyrrhenian Basin). The interval of each histogram class (axial diameter) is $10 \mu$. Interval classes concerning the periphery are as follows: (1) subacute periphery, (2) acute periphery, (3) imperforate keel in the last-formed chamber, (4) imperforate keel in the last and penultimate chambers, (5) imperforate keel on three or more chambers. 
the author locates the boundary between the two lineagezones based on the evolution of Globorotalia margaritae.

It is regrettable that full documentation cannot be presented here, but the limitation of time (and also of space) was such that it was absolutely impractical; it is only possible to present the conclusions here. In fact, three taxa were distinguished by the author within the Globorotalia margaritae group, giving them subspecies rank; namely, $G$. margaritae primitiva, G. margaritae margaritae, and $G$. margaritae evoluta. They co-occur in the latest part of the range of the group, as in Sample DSDP 132-14, CC, from which come all the specimens illustrated in Plates 1-2, and which represents the type locality for the two new taxa. $G$. margaritae evoluta is common in the upper half of the range of the taxon, to which it is practically limited. Bolli (1970, p. 581) found that ". . . in the upper part of the Globorotalia margaritae Zone of Sites 29 and 31 (Venezuela Basin), they have a tendency to grow larger by adding one or two more chambers." The specimens illustrated (Plate 8, Figures 4-7) compare well with our $G$. margaritae evoluta. Beckmann (personal communication) found in the eastern North Atlantic (DSDP Leg 14) (always in the later part of the range of $G$. margaritae) a similar large form, with an equatorial periphery less elongated than in the typical form (here named $G$. margaritae margaritae). G. margaritae primitiva represents the most primitive type, and is more common in the lower levels.

We used these names in the range charts of the various sites, so we are obliged to describe and figure here the taxa, which otherwise should be invalidated as "nomina nuda." Further information on these taxa and on their variability will follow this first formal description.

\section{Description of the New Taxa}

Globorotalia margaritae evoluta $\mathrm{n}$. subsp. (Plate 1, Figures 1-7)

Globorotalia margaritae (large-sized specimens) of Bolli, 1970, Plate 8, Figures 4 to 7.

Description: Large and compressed form, almost symmetrically biconvex, with a low trochospire. First coils indistinct, however clearly eccentric.

Equatorial periphery subrounded to slightly elongate, lobulate. Axial periphery acute to keeled in the last whorl. A distinctly imperforate keel is visible on at least two chambers (last-formed and penultimate). Extended hispidity is observed on the early ontogenetic stages. Growth pattern regular, with a slower increase in both the height and the width of the chambers than in G. margaritae margaritae. An abortive (negative) final chamber is often recorded (see Plate 1, Figures 3 and 5). Chambers petaloid, separated by gently arched intercameral sutures; they are distinctly limbate in the last two or three (keeled) chambers, then become flush and are generally indistinct at the beginning of the last-formed whorl, which includes 4.5 to 6 chambers (generally 5). Intercameral sutures radial and slightly depressed on the umbilical side, which shows a narrow and shallow umbilicus. Slit-like aperture, umbilicalextraumbilical, with an apertural lip. Wall calcareous, distinctly perforate, surface smooth (in the last two or three chambers of the last-formed whorl) to hispid (in the previous ones) on the spiral side, as well as on the umbilical side, where the hispidity is even more extended and accentuated, as evidenced by the scanning-electron photomicrographs. Coiling dominantly left.

Dimensions: Equatorial diameter (passing through the last chamber) $0.5 \cdot 0.6 \mathrm{~mm}$; equatorial diameter perpendicular to the above one, $0.4-0.5 \mathrm{~mm}$; and axial diameter averaging $0.2 \mathrm{~mm}$.

Type locality: DSDP Site 132, Tyrrhenian Basin.

Latitude: $40^{\circ} 15.70^{\prime} \mathrm{N}$

Longitude: $11^{\circ} 26.47^{\prime} \mathrm{E}$

Subbottom depth 122 meters

Type level: DSDP Core 132-14, CC.

Discussion: Globorotalia margaritae evoluta is considered to be phylogenetically derived from $G$. margaritae margaritae in the latest part of its evolution. It differs from the latter by its greater size, less elongated equatorial outline, slower increase in height of the chambers, and more symmetrical axial profile. Globorotalia margaritae evoluta also differs from Globorotalia hirsuta praehirsuta Blow in its larger size, more rounded outline, less rapid growth of the chamber height, and more distinct keel. Further comparisons with morphologically similar taxa will follow, along with a thorough documentation on the variability of the new taxon.

\section{Globorotalia margaritae primitiva $\mathrm{n}$. subsp.}

(Plate 2, Figures 1-3)

Description: Fairly small form, almost symmetrically biconvex, with a low trochospire. Equatorial periphery subrounded to slightly elongate, with a faint lobulation. Axial periphery subacute, never keeled, not even in the last-formed chamber. Growth pattern regular, with a slower increase in both the height and in the width of the chambers than in $G$. margaritae margaritae. Chambers petaloid, separated by gently arched intercameral sutures, which are never limbate, but are flush to indistinct on the spiral side. Intercameral sutures subradial and slightly depressed on the umbilical side. Fairly small and shallow umbilicus; aperture slit-like, extending to the periphery, with a distinct apertural lip. Chamber wall calcareous, distinctly perforate, with an extended superficial hispidity in the early ontogenetic stages. Coiling dominantly left.

Dimensions: Equatorial diameter (passing through the last-formed chamber) 0.3-0.4 $\mathrm{mm}$; equatorial diameter, perpendicular to the above, $0.25-0.35 \mathrm{~mm}$; and axial diameter averaging $0.19 \mathrm{~mm}$.

Type locality: DSDP Site 132, Tyrrhenian Basin. Latitude: $40^{\circ} 15.70^{\prime} \mathrm{N}$

Longitude: $11^{\circ} 26.47^{\prime} \mathrm{E}$

Subbottom depth 122 meters.

Type level: DSDP Core 132-14, CC.

Discussion: Globorotalia margaritae primitiva is considered to be phylogenetically related to $G$. margaritae margaritae with which it co-occurs for most of its range in the Lower Pliocene. It differs from the latter by its smaller size, less elongate equatorial outline, slower increase in size of chambers, more symmetrical axial profile, and complete lack of a distinct keel. In addition, it differs from Globorotalia praemargaritae Catalano and Sprovieri for having a more elongate test, a more acute axial periphery, a more rapid growth pattern, and left coiling. Further 
comparisons with morphologically similar taxa will follow, along with a thorough documentation of the variability of the new taxon.

\section{WHY A NEW ZONATION?}

A new zonation is proposed here for a number of reasons which will be discussed before defining the biozones.

1) The climatic evolution of the earth during the latest portion of its history is such that ecologically controlled variations in the planktonic foraminiferal assemblages become more and more important. Therefore, while we can accept the principle of a standard zonation for the Upper Cretaceous, it is practically meaningless to speak of a world-wide zonation for the Pliocene.

2) The crisis of salinity which occurred in the latest part of the Miocene in the Mediterranean area resulted in the extermination of the planktonic fauna living there. According to the model presented in Chapter 43 of this volume, the Pliocene fauna re-immigrated from the Atlantic into the Mediterranean in a quite unusual way. The re-immigration was not only climatically controlled, but was also controlled by the activity of geostrophic currents, influenced by the morphology of the Gibraltar threshold (see Chapters 36.2 and 40). Therefore, the Mediterranean successions, which are less diverse than the Atlantic ones and in some ways more "provincial," deserve a zonation of their own.

3) A standard zonation for the Mediterranean does not exist. A number of more or less similar zonations have been proposed since 1967, including those of Bizc 1 (1967) for NW Greece; Barbieri (1967) for Northern Apennines (Vernasca-Castellanquato section); Colalongo and Sartoni (1967) for Northern Apennines; Conato and Follador (1967) for Southern Italy; Colalongo (1968) for Northern Apennines; d'Onofrio (1968) for the Marche, central Italy; Mansour et al. (1969) for Egypt; and Mazzola (1971) for Algeria. Some of the zonations presented independently at the Fourth Congress of the Mediterranean Neogene Stratigraphy (CMNS) held in Bologna in 1967 have been integrated in a unified zonation (Bertolino et al., 1968).

A comparison of the taxa, and of the range of the taxa, was requested (see Report on Micropaleontology by Cita, 1968) during the aforementioned Congress. This was promoted and actually realized by Hans Bolli, chairman of a meeting held in Bologna (May, 1968), and represented a kind of appendix to the Fourth Congress of the Mediterraranean Neogene Stratigraphy (CMNS). The meeting resulted in a paper signed by 21 authors (Cati et al., 1968), in which three different zonations were proposed for the Pliocene (Figure 8), since no general consensus could be reached on any one of them.

4) Most of the biostratigraphical subdivisions defined in the cited papers (Figure 8) are assemblage zones or cenozones. This is especially true of the paper by Bertolino et al. (1968). It includes a definition of the cenozone which is also cited in the glossary attached to Circular No. 36 of the Subcommission on Stratigraphy Classification, IUGS (July, 1971).

Assemblage zones are obviously ecologically controlled and are a very useful tool for subdividing the stratigraphic record of epicontinental sedimentary basins. Most of the sections investigated by Mediterranean researchers are outer shelf deposits, or in some instances inner shelf deposits. Also, subsurface sections (see Dondi and Papetti, 1968) represent sedimentation in rapidly subsiding, but certainly not deep basins.

Assemblage zones can hardly be correlated from one basin to another, and their boundaries cannot theoretically be considered isochronous over broad geographic regions.

Because the philosophic background is very different, and since for practical reasons we cannot consider the zonal boundaries as correlatable (in time-stratigraphic correlations), none of the previously defined zonations were used by the author, even in cases where the same zonal marker is used (for example, Globorotalia margaritae and Globorotalia inflata).

The author always tried to work on ranges instead of assemblages, and in deep-sea pelagic sediments certainly this is possible.

5) Some of the taxa used as zonal markers in the Mediterranean, such as Globorotalia crassaformis and $G$. aemiliana, appear to be strongly affected by some ecological factors (see the introduction to this chapter).

Since the assemblage-zones derive their names from these taxa and are defined in their lower boundaries by the first recorded occurrence of the zonal marker, the questions arise: are the correlations based on their first occurrences indeed isochronous, or are they diachronous, and do they only correspond to similar ecological conditions? These questions are critical for the determination of the relative ranges of Globorotalia margaritae (group) and G. crassaformis (group), as discussed on many occasions with Sartoni, Sprovieri, Crescenti, and others. The problem has been pointed out also by Ruggieri, Catalano and Sprovieri (1968) and is expressed graphically in Figure 7.

While an overlap in the ranges of the two named taxa was not found at Site 132 (Tyrrhenian Basin), it was found in the Ionian Basin (Core 125A-5-4). An overlap of these taxa has also been recorded by Catalano (1969) in Sicily. Moreover, at Anzio, the type locality of Globorotalia hirsuta praehirsuta Blow, there is a co-occurrence of Globorotalia crassaformis and G. margaritae.

Thus, either the extinction horizon of Globorotalia margaritae or the first occurrence of $G$. crassaformis is isochronous. Both biostratigraphic events cannot be isochronous, since the taxa are known to co-occur in certain outcrops and be mutually exclusive at others.

Sartoni and his colleagues believe that a correlation based on the first occurrence of Globorotalia crassaformis is a time correlation unlike a correlation based on the last occurrence of $G$. margaritae. It is likely that in terrigenous deposits the range of a keeled Globorotalia may be restricted due to a paleoenvironmental control, as is the case for the range of $G$. menardii (group) in the Serravallian-Tortonian interval of Northern Italy (Tertiary Basin of Piedmont). However, in purely pelagic sediments, such as those recovered during Leg 13 , this assumption is unrealistic.

The evidence given by DSDP cores in the Mediterranean support the isochroneity of the extinction horizon of $G$. margaritae, as discussed in Chapter 40 of this volume. The consistency of the relative thickness of the overlying 


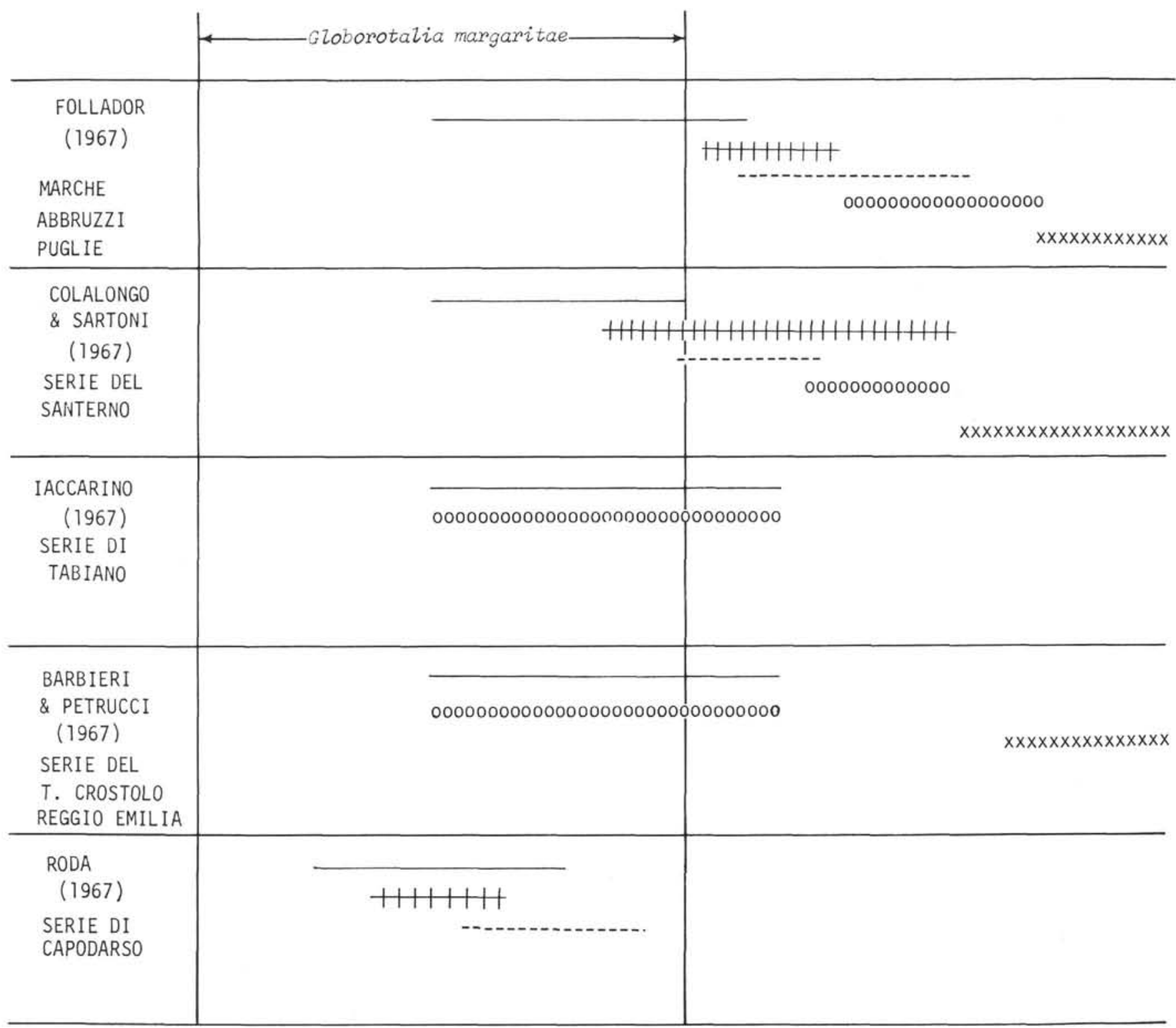

\begin{tabular}{|c|c|}
\hline & Globorotalia puncticulata (DESHAYES) \\
\hline $\mathrm{H} H \mathrm{H} H$ & Globorotalia bononiensis DONDI \\
\hline 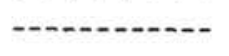 & Globorotalia crassaformis aemiliana COLALONGO \& SARTONI \\
\hline 000000000000 & Globorotalia crassaformis (GALLOWAY \& WISSLER) \\
\hline$x x x x x x x x y$ & Globorotalia inflata (D'ORBIGNY) \\
\hline
\end{tabular}

Figure 7. Range of some species of Globorotalia in the Pliocene of Italy as indicated by various authors, with reference to the range of Globorotalia margaritae. After Ruggieri, Catalano and Sprovieri (1968), slightly modified.

foraminiferal zones in the various drilling sites and the correlation, consistent everywhere with the nannofossil zones as identified by both H. Stradner and D. Bukry, are arguments in favor of this biohorizon being isochronous.

A third argument is now offered by the paleomagnetic investigations carried out on Site 132 (see Chapter 19, this volume). In fact, the Gauss/Gilbert boundary, which coincides in Pacific cores with the extinction horizon of $G$. margaritae (see Hayes et al., 1969), at Site 132 in Core 14, Section 3, falls within one meter of the last occurrence of G. margaritae.

\section{DEFINITION OF THE BIOZONES}

The foraminiferal zones here defined are named according to the internationally agreed-upon rules recently pro- 
47.1. PLIOCENE BIOSTRATIGRAPHY AND CHRONOSTRATIGRAPHY

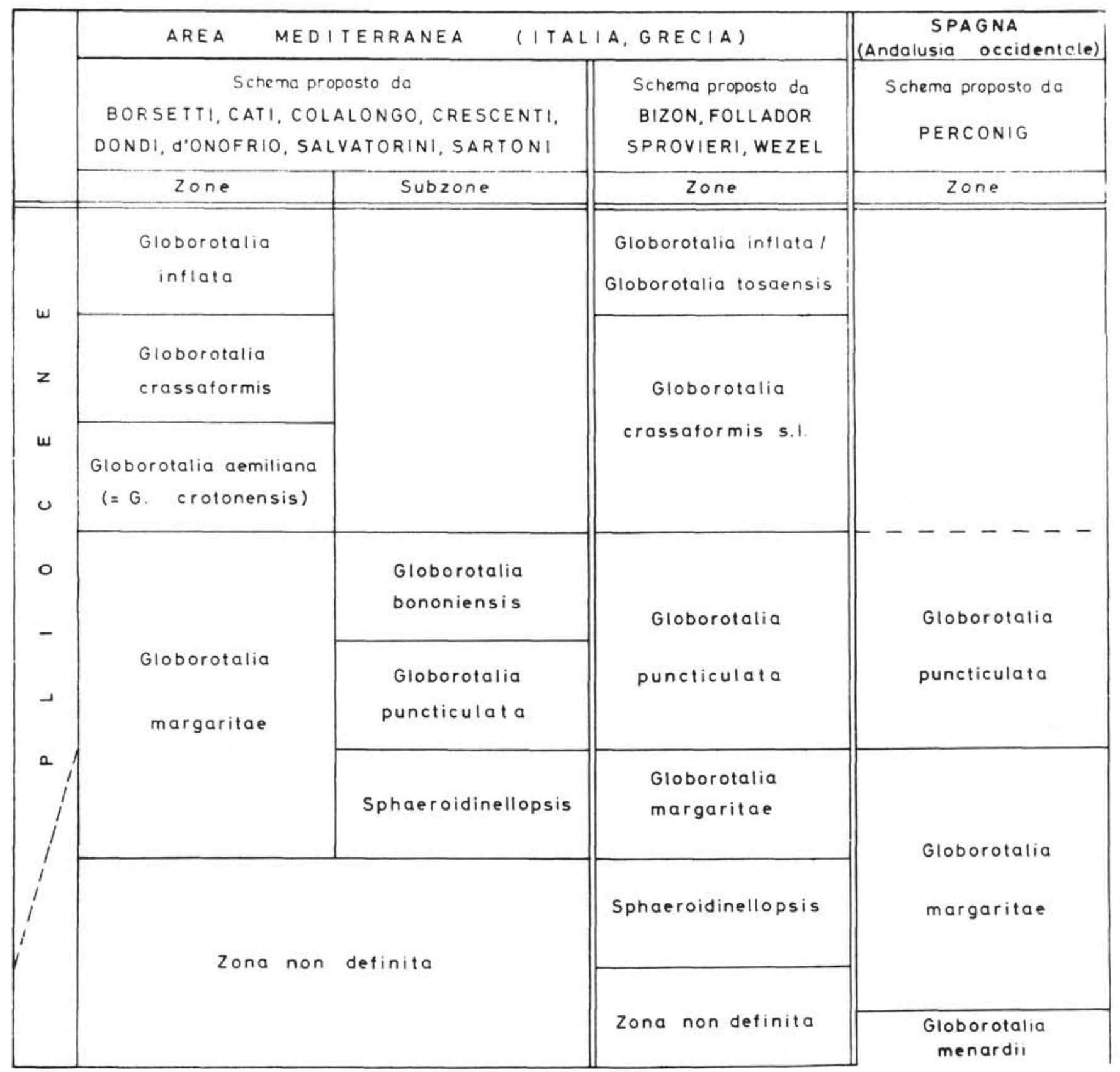

Figure 8. Mediterranean foraminiferal zonations proposed for the Pliocene of Italy, Greece and Spain. After Cati et al. (1968).

posed by the Subcommission on Stratigraphy, chaired by Prof. H. D. Hedberg (Circular No. 36, July, 1971). ${ }^{5}$

Six zones are distinguished in the Pliocene. One of them is an acme zone, which is characterized by the (ecologically controlled) abundance of a given taxon. Two are lineage

\footnotetext{
${ }^{5}$ Professor Hedberg has critically read an earlier draft of this manuscript. He has offered comments on the present zonation, with which he agrees, suggesting some more exhaustive terminology. Since zonal names have to be repeated many times and be referred to in reports, range charts, and discussions, the author believes that a complex terminology may be too cumbersome. The terms suggested by Prof. Hedberg are indicated in footnotes that follow.
}

zones, based on the evolution observed in the Globorotalia margaritae group. Three are interval zones, based on a combination of biostratigraphical events. All except the first are based on ranges of taxa, and therefore, according to the previously mentioned rules, no type section is designated. Type sections are designated only for assemblage-zones. However, some cored intervals which are considered characteristic of the various zones will be mentioned as reference sections. The present zonation is suitable for deep-sea sediments of the Mediterranean area.

\section{Sphaeroidinellopsis Acme Zone}

This interval is characterized by the abundance of 
representatives of the genus Sphaeroidinellopsis (S. seminulina and $S$. subdehiscens) and is related to the catastrophic transgression which occurred after the collapse of the dam separating the desiccated Mediterranean basins from the Atlantic (see Chapter 43). The genus Globorotalia is represented in this interval by the species $G$. acostaensis, $G$. humerosa, $G$. obesa and $G$. scitula, none of which is common.

The Sphaeroidinella datum apparently falls within this zone. In fact, forms showing incipient supplementary apertures on the spiral side are recorded in Core 132-21-1, 60-62 cm (see Plate 6, Figure 5).

Discussion: The lower and upper boundaries of an acme-zone are self-explanatory. Where the acme terminates, the zone terminates. The lower boundary of the zone generally coincides with a disconformity, underlain by deposits of latest Miocene age (Globorotalia plesiotumida Zone [foraminiferal], Discoaster quinqueramus Zone [nannofossil]).

A Sphaeroidinellopsis Zone (or subzone) is recognized by practically all researchers in the Mediterranean region; it is assigned to either the basal Pliocene (see Bizon, 1967; Mansour et al., 1969; d'Onofrio, 1968; Bertolino et al., 1968; Colalongo, 1968; Dondi and Papetti, 1968) or an interval straddling the Miocene/Pliocene boundary (see Cati, et al., 1968; Mazzola, 1971). For instance, Blow (1969) recorded the Sphaeroidinella datum, defining the Zone N.18/Zone N.19 boundary, in the lower part of the "Trubi" marls in Sicily. Bizon (1967) recorded forms transitional from Sphaeroidinellopsis to Sphaeroidinella in her Sphaeroidinellopsis sp. Zone in Greece. Therefore, a certain consistency appears also from the literature concerning the first evolutionary appearance of Sphaeroidinella in the lowermost part of the Pliocene of the Mediterranean area.

The Sphaeroidinellopsis Acme-zone corresponds to the lowermost part of the Ceratolithus tricorniculatus Zone (nannofossil), as identified by H. Stradner in the Mediterranean cores.

Thickness: The thickness of the Sphaeroidinellopsis Acme-zone in the Tyrrhenian Basin (Site 132) is about 10 meters.

Reference sections: DSDP Cores 132-21-1, 132-20 (Sections 3 and 4).

\section{Globorotalia margaritae margaritae Lineage-zone ${ }^{6}$}

Interval with the zonal marker from the end of the acme of Sphaeroidinellopsis to the statistically demonstrated transition toward more evolute forms of $G$. margaritae (namely, G. margaritae evoluta).

Discussion: $G$. margaritae margaritae is usually common to abundant in this interval, and co-occurs with $G$. margaritae primitiva. Also, forms transitional to $G$. margaritae evoluta are occasionally present, especially in the uppermost part of the zone. Other members of the genus Globorotalia present include $G$. acostaensis, $G$. humerosa, $G$. obesa, and $G$. scitula. The tests of Sphaeroidinellopsis spp. rarely occur in this zone.

${ }^{6}$ Or lineage-segment zone according to Hedberg (1971), since it is defined by a given part of the total evolution of the taxon.
The Globorotalia margaritae margaritae Lineage-zone consistently corresponds to the upper part of the Ceratolithus tricorniculatus Zone, as identified in the Mediterranean cores by $\mathrm{H}$. Stradner.

Thickness: The thickness of the Globorotalia margaritae margaritae Lineage-zone in the Tyrrhenian Basin (Site 132) is 25.5 meters.

Reference sections: DSDP Cores 132-18, 132-19, 13120 (Sections 1 and 2); 134-7 (Sections 1 and 3); 124-4.

\section{Globorotalia margaritae evoluta Lineage-zone ${ }^{7}$}

Interval with the zonal marker, from the statistically demonstrated transition of the taxon from $G$. margaritae margaritae upward to the extinction horizon of Globorotalia margaritae (group).

Discussion: This interval can easily be identified by the concurrent range of Globorotalia margaritae (sensu lato) and Globorotalia puncticulata, which usually is abundant throughout. An overlap in the ranges of Globorotalia margaritae (group) and of $G$. crassaformis (group) has been recorded in Core 125A-5-4.

The Globorotalia margaritae evoluta Lineage-zone consistently corresponds to the Ceratolithus rugosus Zone (nannofossil), as identified by H. Stradner in the Mediterranean cores.

Thickness: The thickness of the Globorotalia margaritae evoluta Lineage-zone in the Tyrrhenian Basin (Site 132) is about 27 meters.

Reference Sections: DSDP Cores 132-14, CC, 132-15, 132-16, 125A-5 (Sections 3 and 4), 125A-6-1 (upper part); $134-6 ; 124-3$ (Section 2).

\section{Sphaeroidinellopsis subdehiscens Interval-zone ${ }^{8}$}

Interval with the zonal marker from the extinction horizon of Globorotalia margaritae (group) to the extinction horizon of representatives of the genus Sphaeroidinellopsis.

Discussion: The zonal marker is never abundant in this interval, nor do we find Sphaeroidinellopsis seminulina in abundance. Globorotalia puncticulata is usually well represented, and may be common, as was the case at Site 125 . However, at Site 132 this species is very rare in this zone. Globorotalia aemiliana is represented in this zone at Site 125 , but neither it nor Globorotalia crassaformis have been recorded in this zone at Site 132. Globigerinoides obliquus extremus is present throughout the interval. Globoquadrina altispira is commonly recorded in this zone at Site 125 , but is more scarce at Site 132. It becomes extinct near the top of the zone. The extinction horizon of Sphaeroidinellopsis spp. consistently falls in the lower part of the Discoaster surculus Zone, as identified by H. Stradner in the Mediterranean cores.

\footnotetext{
${ }^{7}$ Since this zone virtually coincides with the total range of $G$. margaritae evoluta, which disappears along with the other subspecies of $G$. margaritae at the Gilbert/Gauss boundary, the name suggested by Prof. Hedberg is Globorotalia margaritae evoluta Taxon-range-Zone.

${ }^{8}$ Suggested name: Globorotalia margaritae exit-to-exit Sphaeroidinellopsis Interval-zone .
} 
Thickness: The thickness of the Sphaeroidinellopsis subdehiscens Interval-zone in the Tyrrhenian Basin (Site 132 ) is 16.5 meters.

Reference sections: DSDP Cores 132-12 (Sections 5 and 6), 132-13, 132-14 (Sections 1-3); 125-6 (Section 3), 125-6; $125 \mathrm{~A}$, Cores 4 and 5 (Sections 1 and 2); 134-3 and 134-5; 124-3 (Section 1).

\section{Globigerinoides obliquus extremus Interval-zone ${ }^{9}$}

This interval with the zonal marker from the extinction horizon of Sphaeroidinellopsis spp. to the massive extinction of the zonal marker.

Discussion: Globigerinoides obliquus extremus is one of the most characteristic constituents of the Pliocene deepsea deposits, and is common to abundant within this zone, as well as below it. The extinction horizon is clearly recognizable at all the sites investigated, and consistently falls in the lower part of the Discoaster brouweri Zone, as identified by H. Stradner. Single teratological specimens of the subspecies may occasionally be recorded from above the extinction horizon. The upper boundary of the zone almost coincides with the first appearance of Globorotalia inflata, which probably evolved from $G$. punticulata. Transitional forms are found within this zone. An overlap of Globigerinoides obliquus extremus in abundance and of Globorotalia inflata (typical form) was never seen in the DSDP Mediterranean cores.

Globorotalia tosaensis was occasionally recorded in this interval in the Ionian Basin (Holes 125, 125A). The greatest development of the Globorotalia crassaformis group is recorded in the present zone.

Thickness: The thickness of the Globigerinoides obliquus extremus Interval-zone in the Tyrrhenian Basin (Site $132)$ is 18 meters.

Reference sections: DSDP Cores 132-10 (Sections 2 to 6), 132-11, 132-12,132-13,132-14 (Sections 1 to 3); $125-5$ (Sections 2 to 3), 125-6; 125A, Cores 2 and 3; 124, Core 2 (Section 4).

\section{Globorotalia inflata Interval-zone $\mathrm{e}^{10}$}

Interval with the zonal marker from the extinction horizon of Globigerinoides obliquus extremus to the first appearance of Globorotalia truncatulinoides (total range).

Discussion: Globorotalia inflata is common in this interval, and G. tosaensis is present in some samples. The latter taxon is present nowhere in abundance in the Mediterranean, so that the evolution to $G$. truncatulinoides cannot be followed step by step. Only at Site 125 were we able to locate this zonal boundary directly (in Core 125-4-5) without referring to the Discoaster brouweri extinction horizon. Since the two biohorizons are virtually identical, in absence of $G$. truncatulinoides we can use the Discoaster extinction to identify the zonal boundary. When conical Globorotalias are absent, the transition from the latest part of the Pliocene to the earliest part of the Pleistocene is very gradational.

\footnotetext{
${ }^{9}$ Suggested name: Sphaeroidinellopsis exit-to-exit Globigerinoides obliquus extremus Interval-zone.

${ }^{10}$ Suggested name: Globigerinoides obliquus extremus exit-to-entry Globorotalia truncatulinoides Interval-zone.
}

Globorotalia crassaformis is present in various amounts in the lower part of this zone. Globigerina apertura apparently becomes extinct within this zone, as does Globigerinoides bollii. Neither species has ever been recorded in the Pleistocene of the Mediterranean. Globigerina pachyderma is recorded in this zone, being represented by right-coiling specimens.

The Globorotalia inflata Interval-zone consistently corresponds to the latest part of the Discoaster brouweri Zone (nannofossil), as identified by H. Stradner in the Mediterranean cores.

Thickness: The thickness of the Globorotalia inflata Interval-zone is 12.5 meters in the Tyrrhenian Basin (Site 132).

Reference sections: DSDP Cores 132-9, 132-10 (Section 1); 125-4 (Section 6); 125A-1.

\section{CORRELATION WITH OTHER ZONATIONS}

A correlation with the standard zonation of Bolli (1966a) is not attempted because this zonation, which is excellent for the pre-late Miocene, seems not to be reliable in its uppermost part. Instead of the standard zonation, the new zonation proposed for the Caribbean deep-sea deposits is considered here (Bolli, 1970). Two correlations are considered as certain: that based on the first occurrence of Globorotalia truncatulinoides and that based on the extinction of Globorotalia margaritae. They are indicated with continuous lines in Figure 9. Dotted lines indicate the correlations which are probable, but not as certain as the two previously mentioned; namely, the base of the Globorotalia margaritae Zone, which supposedly falls in our Globorotalia plesiotumida Zone of late Miocene age (see previous discussion), and the top of the Globorotalia exilis-G. miocenica Zone, which is indicated as more restricted than our Globorotalia inflata Interval-zone. During a discussion of the new Caribbean zonation by $\mathrm{H}$. Bolli (CMNS Congress, Lyon, 1971), both W. H. Blow and W.A. Berggren argued that $G$. exilis and $G$. miocenica extend to the topmost part of the Pliocene, and that even overlaps of $G$. exilis and $G$. truncatulinoides are recorded. The personal experience of the writer in the deep-sea Pliocene deposits of the Cape Verde DSDP Site 12, however, has not shown this overlap. Also Beckmann (personal communication) found in the central Atlantic a definite, though short, interval between the last occurrences of $G$. exilis and G. miocenica and the first occurrence of $G$. truncatulinoides. H. Bolli (personal communication), after studying the material recovered from DSDP Leg 15 has confirmed his previous observations and has found that $G$. miocenica disappears slightly earlier than $G$. exilis.

With regard to Blow's (1969) standard zonation, one correlation is considered certain - that based on the first occurrence of Globorotalia truncatulinoides. One more correlation is considered good - that based on the extinction horizon of Sphaeroidinellopsis (new zonation) and the top of Zone N 19. Two more correlations are fairly good: the base of $\mathrm{N} 21$ (first occurrence of Globorotalia tosaensis) at about the middle of our Globigerinoides obliquus extremus Interval-zone, where we sometimes recorded Blow's zonal marker; and the Zone N 18/Zone $\mathrm{N} 19$ boundary, based on the first occurrence of the genus 


\begin{tabular}{|c|c|c|c|}
\hline AGES & $\begin{array}{l}\text { PRESENT PAPER } \\
\text { MEDITERRANEAN }\end{array}$ & $\begin{array}{l}\text { BOLLI } 1970 \\
\text { CARIBBEAN }\end{array}$ & $\begin{array}{l}\text { BLOW } 1969 \\
\text { STANDARD }\end{array}$ \\
\hline 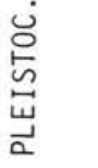 & $\begin{array}{r}\text { Globorotalia truncatulinoides } \\
\text { Total-range-zone }\end{array}$ & Globorotalia truncatulinoides & N.22 \\
\hline \multirow{3}{*}{$\begin{array}{l}\text { 采 } \\
\text { 음 }\end{array}$} & $\begin{array}{l}\text { Globorotalia inflata } \\
\text { Interval-zone }\end{array}$ & \multirow[t]{3}{*}{ 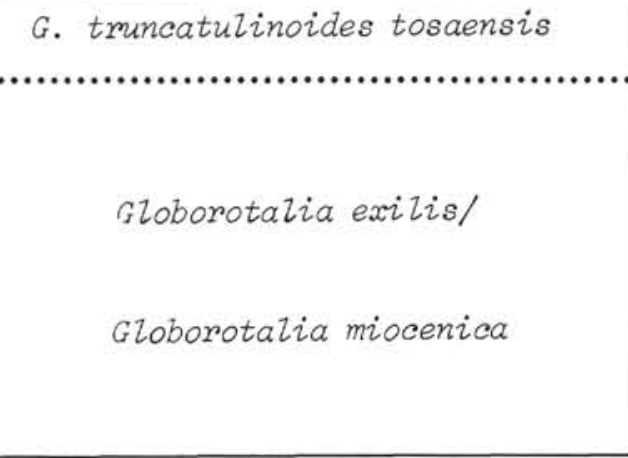 } & \multirow[b]{2}{*}{$\frac{-}{N .20}$} \\
\hline & $\begin{array}{c}\text { Globigerinoides obliquus extremus } \\
\text { Interval-zone }\end{array}$ & & \\
\hline & $\begin{array}{c}\text { Sphaeroidinezlopsis subdehiscens } \\
\text { Interval-zone }\end{array}$ & & \multirow{4}{*}{ N. 19} \\
\hline \multirow{3}{*}{ 営 } & $\begin{array}{r}\text { Globorotalia margaritae evoluta } \\
\text { Lineage-zone }\end{array}$ & \multirow{4}{*}{ Globorotalia margaritae } & \\
\hline & $\begin{array}{r}\text { Globorotalia margaritae margaritae } \\
\text { Lineage-zone }\end{array}$ & & \\
\hline & $\begin{array}{l}\text { Sphaeroidinelzopsis } \\
\text { Acme-zone }\end{array}$ & & \\
\hline 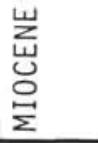 & $\begin{array}{r}\text { Globorotalia plesiotumida } \\
\text { Zone }\end{array}$ & & $\begin{array}{l}\text { N. } 18 \\
\text { N. } 17\end{array}$ \\
\hline
\end{tabular}

Figure 9. Proposed correlation of various foraminiferal zonations. The Mediterranean zonation is in time-equivalent spacing.

Sphaeroidinella falling in our Sphaeroidinellopsis Acme-zone.

Correlations with some of the zonations recently proposed for the Mediterranean are indicated in Figure 10.

The easiest correlations are those of the lowermost zone (Sphaeroidinellopsis Zone) and the topmost one (Globorotalia inflata Zone) which are common to all of the previous zonations and are considered by everyone to be isochronous. The correlations of the zones lying in between are more or less tentative, because of the different criteria followed in the definition of the zonal boundaries. For instance, all the zonations include a Globorotalia margaritae (or G. hirsuta) Zone; however, we cannot correlate its upper boundary from one zonation to the other one, since in most cases $G$. margaritae is absent in the upper part of the zone. Further discussions of this critical argument are presented in a subsequent part of this chapter.

The best documented correlation is with the zonation of Bizon (1967): extinction of $G$. margaritae near the middle of the Globorotalia puncticulata Zone; extinction of Sphaeroidinellopsis near the top of the Globorotalia puncticulata Zone.

A check of the previously discussed correlations with Bolli's (1966a, 1970) and Blow's (1969) zonations via nannoplankton, as investigated in the DSDP Legs $2,4,7$, should be possible.

In the Pliocene succession at Cape Verde (DSDP Site 12), where the planktonic foraminifera were studied by the writer, two definite extinction horizons were recognized by Gartner (1969): the Ceratolithus tricorniculatus extinction horizon and that of Reticulofenestra pseudoumbilica. The former occurs immediately above Core $12 \mathrm{C}-4-2,100 \mathrm{~cm}$. Cita (1971) recognized Datum VII of Saito (first coiling change of Pulleniatina from left-coiling (below) to rightcoiling (above) immediately above Core DSDP 12C-4-2, 76 $\mathrm{cm}$. Datum VII of Saito occurs just above event "a" of the Gilbert epoch (see Hays et al., 1969). But the Ceratolithus tricorniculatus extinction horizon, as recorded in the 


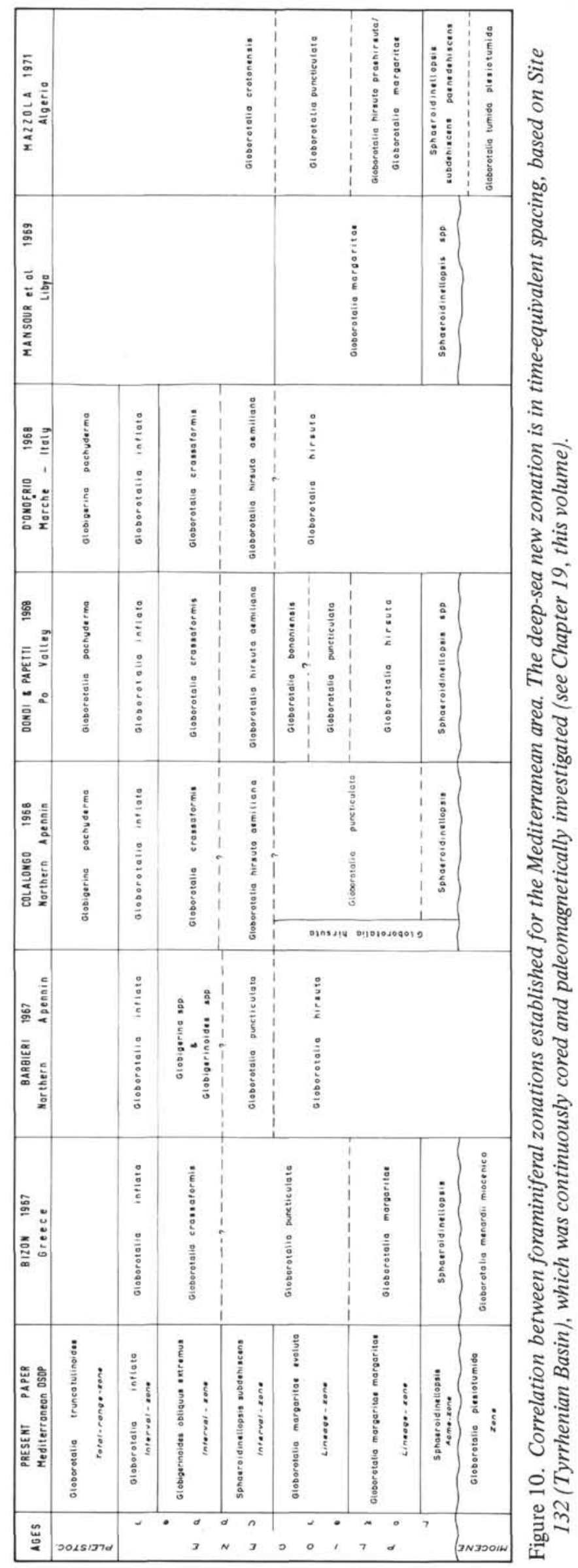

Mediterranean cores, consistently corresponds to the topmost part of the range of Globorotalia margaritae and almost coincides (slightly higher) with the extinction horizon of G. margaritae (Datum VI of Saito). This latter coincides with the Gilbert/Gauss boundary both in the equatorial Pacific (see Hayes et al, 1969) and in the Mediterranean (see Chapter 47.2).

The extinction horizon of Reticulofenestra pseudoumbilica occurs at Cape Verde above Core 12C-4-2, $2 \mathrm{~cm}$ (Gartner, 1969, Figure 4) which means below Datum V of Saito, as identified by Cita (1971) in Core 12C-4-1, $102 \mathrm{~cm}$, based on the extinction horizon of Sphaeroidinellopsis (Mammoth event of the Gauss normal epoch). The relative position of the two biostratigraphic events is consistent with that found in our cores (see Figures 11 and 12). However, in the Mediterranean, Reticulofenestra pseudoumbilica is also recorded in the Pleistocene (see observations by H. Stradner in Chapters 7, 9 and 13). At the

\begin{tabular}{|c|c|c|c|}
\hline AGE & FORAMINIFERAL ZONES & NANNOFOSSIL ZONES & 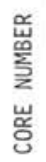 \\
\hline \multirow{7}{*}{$\begin{array}{l}\text { 岂 } \\
\text { 。 } \\
\text { 늠 } \\
\vec{u} \\
\vec{a}\end{array}$} & \multirow{7}{*}{$\begin{array}{l}\text { Globorotalia } \\
\text { truncatulinoides } \\
\text { Total-range-zone }\end{array}$} & \multirow{2}{*}{ Emiliania huxleyi zone } & 1 \\
\hline & & & 2 \\
\hline & & \multirow{2}{*}{$\begin{array}{c}\text { Gephyrocapsa oceanica } \\
\text { Zone }\end{array}$} & 3 \\
\hline & & & 4 \\
\hline & & \multirow{3}{*}{$\begin{array}{c}\text { Pseudoemiliania Zacunosa } \\
\text { Zone }\end{array}$} & 5 \\
\hline & & & 6 \\
\hline & & & 7 \\
\hline \multirow{4}{*}{ 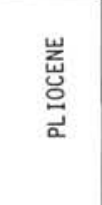 } & $\begin{array}{c}\text { Globorotalia inflata } \\
\text { Interval-zone }\end{array}$ & \multirow{2}{*}{$\begin{array}{l}\text { Discoaster broweri zone } \\
\text { Discoaster pentaradi atus }\end{array}$} & 9 \\
\hline & Globigerinoides obliquos & & 10 \\
\hline & extremus & \multirow{2}{*}{ Discoaster surculus Zone } & 11 \\
\hline & interval-zone & & 12 \\
\hline \multirow[t]{2}{*}{$\begin{array}{l}\text { 采 } \\
\text { 言 }\end{array}$} & \multirow{2}{*}{$\begin{array}{l}\text { Sphaeroidinellopsis } \\
\text { subdehiscens } \\
\text { Interval-zone }\end{array}$} & \multirow{2}{*}{$\begin{array}{r}\text { Reticulofenestra } \\
\text { pseudoumbilica Zone }\end{array}$} & 13 \\
\hline & & & \multirow{2}{*}{14} \\
\hline \multirow{6}{*}{$\begin{array}{l}\text { 崫 } \\
\text { O븜 } \\
\text { a }\end{array}$} & \multirow{3}{*}{$\begin{array}{c}\text { Globorotalia margaritae } \\
\text { evoluta } \\
\text { Lineage-zone }\end{array}$} & \multirow{2}{*}{\begin{tabular}{|c|} 
Discoaster asymmetrious \\
Zone
\end{tabular}} & \\
\hline & & & 15 \\
\hline & & Ceratolithus mugosus Zone & 16 \\
\hline & \multirow{3}{*}{$\begin{array}{c}\text { Globorotalia margaritae } \\
\text { margaritae } \\
\text { Lineage-zone }\end{array}$} & \multirow{5}{*}{$\begin{array}{c}\text { Ceratolithus } \\
\text { tricomiculatus Zone }\end{array}$} & 17 \\
\hline & & & 18 \\
\hline & & & 19 \\
\hline \multirow{2}{*}{ 竝 } & Sphaeroidinellopsis & & 20 \\
\hline & Acme-zone & & 21 \\
\hline $\begin{array}{l}\text { LATE } \\
\text { MIOCENE }\end{array}$ & $\begin{array}{r}\text { Globorotalia plesiotumida } \\
\text { Zone }\end{array}$ & $\begin{array}{c}\text { Discoaster } \\
\text { quinqueramus zone }\end{array}$ & 22 \\
\hline
\end{tabular}

Figure 11. Correlation between foraminiferal zones and calcareous nannoplankton zones, as identified by $\mathrm{H}$. Stradner, at Site 132 (Tyrrhenian Basin), in timeequivalent spacing. 


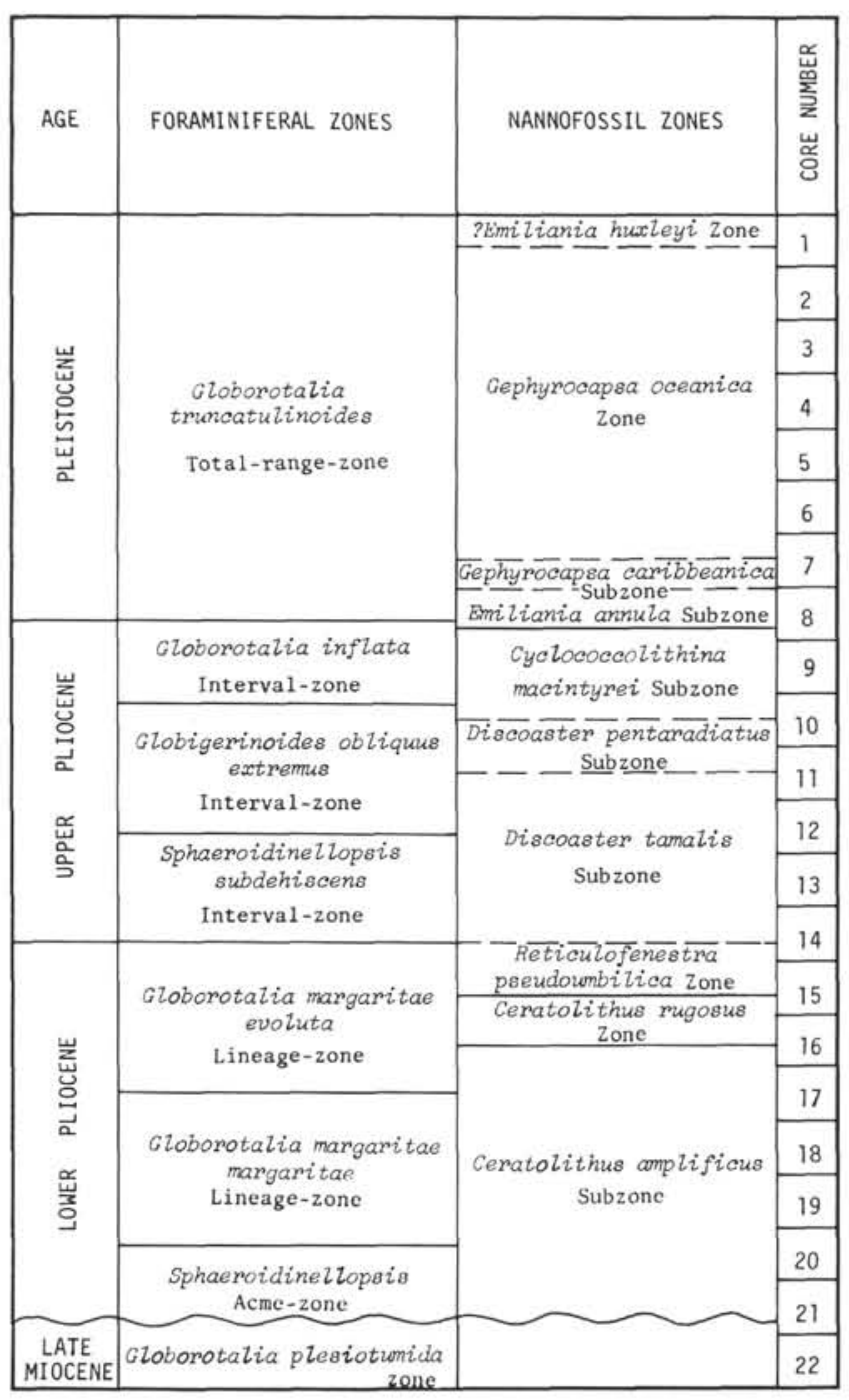

Figure 12. Correlation between foraminiferal zones and calcareous nannoplankton zones, as identified by $D$. Bukry (personal communication, 1971), at Site 132 (Tyrrhenian Basin), in time-equivalent spacing.

Hellenic Trench Sites 127 and 128, a Reticulofenestra pseudoumbilica peak is recorded in the lower part of the Pseudoemiliania lacunosa Zone.

A correlation with the Caribbean based on the same criteria cannot even be attempted. In fact, Hay (1970) does not record either Ceratolithus tricorniculatus or Reticulofenestra pseudoumbilica in the Venezuela Basin (DSDP Sites 29, 30, 31).

A very interesting correlation is possible with the equatorial Pacific (DSDP Leg 7). The nannofossils there were investigated by Martini and Worsley, using their new standard zonation; the foraminiferal zonation of Bronnimann, following Blow's zonal scheme, is shown in Figure 13.

No problem exists for the $\mathrm{N} 22 / \mathrm{N} 21$ zonal boundary, correlated with the Pseudoemiliana lacunosa/Discoaster brouweri zonal boundary.
Zone N 21 includes the Discoaster brouweri Zone, $D$. pentaradiatus Zone, and the topmost part of the $D$. surculus Zone. The base of foraminiferal Zone N 21 falls in the upper part of the Discoaster surculus Zone; this is consistent with our findings (see Figure 11) and with the correlation of various foraminiferal zonations here proposed (see Figure 9).

All of Zone N 20, as shown in Figure 13, falls in the Discoaster surculus (nannofossil) Zone. This is consistent with our findings and with the correlation proposed. There is still doubt, however, as to the exact placement of this zone, because of problems involved in the definition and recognition of its boundaries.

The top of foraminiferal Zone $\mathrm{N} 19$ falls near the base of the Discoaster surculus Zone (nannofossil), according to the paleontologists of DSDP Leg 7. In the Mediterranean, the top of the Sphaeroidinellopsis subdehiscens Interval-zone falls near the base of the Discoaster surculus Zone (see Figure 11), and the top of Blow's Zone N 19 can be easily correlated with the extinction horizon of Sphaeroidinellopsis spp. (see Figure 9). In this case too, a perfect agreement exists between the Mediterranean and the equatorial Pacific.

Foraminiferal Zone N 19 falls in the Ceratolithus tricorniculatus Zone instead of in the $C$. rugusos Zone (see Figure 13, correlation a').

The above discussion indicates that on the basis of available data, the correlation between foraminiferal zones and nannofossil zones has to be carefully established in one basin, but that it cannot be readily extrapolated to other basins without a critical check.

\section{CORRELATION WITH THE STRATOTYPE SECTIONS OF THE PLIOCENE OF ITALY}

Italian stratigraphers commonly use either an informal threefold subdivision of the Pliocene (Figure 14), following Ruggieri and Selli (1948), which is now supported by a detailed biostratigraphic zonation; or a subdivision in two stages (Tabianian for the lower Pliocene and Piacenzian for the middle-upper Pliocene), in agreement with the definition of the stratotypes proposed at the CMNS Congress (Bologna, 1967).

Reference is made to the recently issued volume on stratotypes of the Neogene stages (1971, edited by Carloni, Marks, Rutsch and Selli), where coordinate information on the original definition, type section, and fossil content of each Mediterranean Neogene stage may be found.

In terms of planktonic foraminifera, the Astian cannot be stratigraphically located with any degree of accuracy. It yields stratigraphically insignificant species associated with probably reworked ones (see Sampó, Zappi and Caretto, 1968). Moreover, it has been used less and less in the last years and will not be used here.

The Piacenzian, as stratotypified by Barbieri (1967) in the Arda Valley, includes perhaps the most classical Pliocene localities of the world and also includes significant planktonic foraminifera which allow long-range correlations. Barbieri (1967, 1971a, 1971b) distinguishes the following zones from bottom to top: Globorotalia crassaformis-puncticulata Zone (extending downwards to the upper part of the Tabianian), Globorotalia crotonensis 


\begin{tabular}{|c|c|c|}
\hline NN 21 & Emiliania huxleyi & N. 23 \\
\hline NN 20 & Gephyrocapsa oceanica & \\
\hline NN 19 & Pseudoemiliania lacunosa & N. 22 \\
\hline NN 18 & Discoaster brouweri & \\
\hline NN 17 & Discoaster pentaradiatus & \\
\hline NN 16 & Discoaster surculus & N. 20 \\
\hline NN 15 & Reticulofenestra pseudoumbilica & \\
\hline NN 14 & Discoaster asymmetricus & N. 19 \\
\hline NN 13 & Ceratolithus rugosus & a \\
\hline NN 12 & Ceratolithus tricorniculatus & $\begin{array}{l}\text { N. } 18 \\
a^{\circ}\end{array}$ \\
\hline NN 11 & Discoaster qui nqueramus & N. 17 \\
\hline NN 10 & Discoaster calcaris & N. 16 \\
\hline
\end{tabular}

Figure 13. Correlation between calcareous nannoplankton zones and foraminiferal zones, according to Martinl (1971), in time-equivalent spacing. $a=$ correlation proposed by Martini; $a^{\prime}=$ correlation here proposed, based on the Mediterranean DSDP cores.

\begin{tabular}{|c|c|c|}
\hline $\begin{array}{l}\text { DSDP TIME-STRATI GRAPHIC } \\
\text { FRAMEWORK, } 1970-71 \\
\text { BERGGREN, } 1971\end{array}$ & $\begin{array}{l}\text { RUGGIERI AND } \\
\text { SELLI, } 1948\end{array}$ & $\begin{array}{c}\text { BARBIERI, } \\
1967 \\
1971\end{array}$ \\
\hline PIACENZIAN & $\begin{array}{l}\text { UPPER } \\
\text { MIDOLE }\end{array}$ & PIACENZIAN \\
\hline ZANCLIAN & LOWER & TABIANIAN \\
\hline
\end{tabular}

Figure 14. Subdivisions of the Pliocene.

Zone, Globorotalia crassula Zone, and Globorotalia inflata Zone. The Piacenzian, as stratotypified by Barbieri, corresponds to the middle and the upper Pliocene of a number of Italian researchers (see, for instance, Colalongo and Sartoni, 1967; Crescenti, 1971a, inter alia), and extends upward to the base of the Calabrian, which is locally represented by sands yielding Arctica islandica.

The Tabianian, as stratotypified by Iaccarino (1967) is well defined biostratigraphically in terms of planktonic foraminifera. It yields Globorotalia margaritae (recorded as $G$. hirsuta) from the base to near the top; this species has never been recorded in the overlying Piacenzian, neither at Tabiano, nor in the type section in Arda Valley. Other planktonic fossils recorded include Globoquadrina altispira, Sphaeroidinellopsis seminulina and Globorotalia puncticulata. The last species is recorded from about 50 meters from the base of the section upward. According to Barbieri and Selli (1971), the Tabianian may be subdivided into the Globorotalia margaritae Zone (below) and the Globorotalia crassaformis-puncticulata Zone (above); the latter zone extends upward to the lowermost part of the Piacenzian (see above). Though Iaccarino (1967) recorded Sphaeroidinellopsis seminulina and Sphaeroidinellopsis sp. from the base of the Tabianian, the Sphaeroidinellopsis Acme-zone apparently is not represented there.

This argument is used critically by Crescenti (1971a and b) against the use of the Tabianian stage. Blow (1969) indicated that the Tabianian extends downward further than the Zanclean (see op. cit., Figure 19), reaching down to the Zone $\mathrm{N} \mathrm{17/Zone} \mathrm{N} 18$ boundary. This indication is repeated by Cita and Blow (1969, p. 593), but it is not supported by convincing arguments.

The lowermost part of the Pliocene succession is probably missing at Tabiano, but this is not sufficient reason for rejecting the use of this stage. In fact, most of the Lower Pliocene is represented by richly fossiliferous sediments, which also include some of the planktonic foraminifera commonly used for long-range correlations.

The Zanclean (the name derives from the Latin appellation of Messina, Sicily) has never been stratotypified. It is represented essentially by the "Trubi" marl ("marnes blanches a foraminifères" in Seguenza, 1868), a formation which has not yet been formally defined. The area of Messina is considered unsuitable for the definition of a type section (Roda, 1971). One of the most classical localities for the "Trubi" outcrops is Buonfornello, near Palermo, Sicily. A number of stratigraphically significant taxa are 
recorded from this locality, including Globorotalia margaritae $(=G$. hirsuta in Ruggieri, 1960), Globoquadrina altispira, and Ceratolithus tricorniculatus (Martini, 1971a).

Blow (op. cit., p. 418) states that the evolution of Sphaeroidinella from Sphaeroidinellopsis occurs 40 feet above the base of the "Trubi" in Sicily, but no precise location is given.

The Zanclean stage appears theoretically preferable to the Tabianian, but its use is hampered by the lack of definition of a type section.

From the above discussion we conclude that a convincing correlation is possible between our Pliocene reference section (Site 132) and the stratotype sections of the Pliocene stages. The correlation is illustrated in Figure 15. The terms Lower Pliocene and Upper Pliocene are here used (capitalized) in a formal sense, as synonymous of Tabianian and Piacenzian respectively.

We do not use here, as we did not use in the site chapters and graphical core summaries in Part I of this volume the term "middle Pliocene," commonly used in Italy by a group of scientists, following Ruggieri and Selli (1948).

The writer prefers not to use the more or less informal geochronological units, and wishes to avoid the acceptance of "floating boundaries." If we have no type sections to

\begin{tabular}{|c|c|c|}
\hline AGE & ITALIAN STAGES & MEDITERRANEAN ZONATION \\
\hline 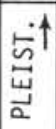 & $\stackrel{\uparrow}{\uparrow}$ & $\begin{array}{c}\uparrow \\
\text { Globorotalia truncatulinoides } \\
\text { Total-range-zone }\end{array}$ \\
\hline \multirow{3}{*}{ 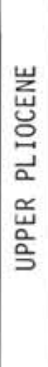 } & \multirow{3}{*}{ 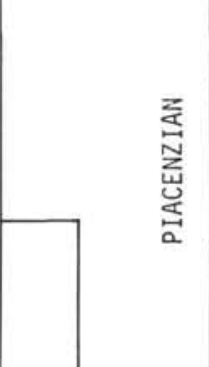 } & $\begin{array}{l}\text { Globorotalia inflata } \\
\text { Interval-zone }\end{array}$ \\
\hline & & $\begin{array}{c}\text { Globigerinoides obliquus extremus } \\
\text { Interval-zone }\end{array}$ \\
\hline & & $\begin{array}{c}\text { Sphaeroidinelzopsis subdehiscens } \\
\text { Interval-zone }\end{array}$ \\
\hline \multirow{3}{*}{ 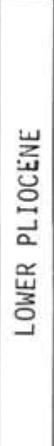 } & 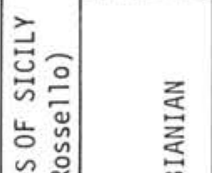 & 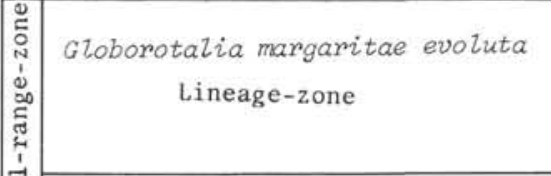 \\
\hline & 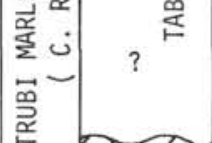 & 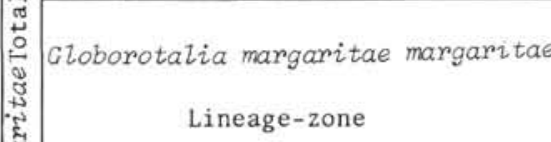 \\
\hline & & $\begin{array}{l}\text { Sphaeroidinellopsis } \\
\text { Acme-zone }\end{array}$ \\
\hline $\begin{array}{l}\text { 崖 } \\
\stackrel{\mathrm{O}}{\Sigma} \\
\end{array}$ & MESSINIAN & ? Globorotalia plesiotumida zone \\
\hline
\end{tabular}

Figure 15. The new deep-sea Mediterranean zonation (in time-equivalent spacing) correlated with the stratotype sections of Italy. which reference can be made, and if we do not have a well-defined biostratigraphy, then the age determinations based on our sections will always be conflicting and confusing.

\section{THE PROBLEM OF THE ANDALUSIAN}

The Andalusian stage was proposed by Perconig at the Third Congress on Mediterranean Neogene Stratigraphy at Berne, 1964, to fill a gap existing in the succession of marine stages. The gap corresponds to the Messinian, which is mostly represented by evaporites in its type section (Selli, 1960), and is not considered suitable for long-range correlations, because of its poor fossil content.

The type area of the Andalusian stage is Andalusia, and the type section designated is at Carmona, near Sevilla. The area was an Atlantic gulf, not connected with the Mediterranean.

The stratigraphic section of Carmona includes the following units, from bottom to top: (a) blue marls; (b) "calizas toscas," calcarenites and sands; and (c) olivegrey marls.

The fossil content of the section originally designated (Perconig, 1966), as presented at the Fourth Congress on Mediterranean Neogene Stratigraphy (Bologna, 1967) (see Perconig 1968a and b), indicates a Pliocene age for most of the section (see Verdenius 1970; see also discussion by Selli and Cita reported in Carloni and Selli, 1971).

Later, the type section of the Andalusian was extended downward into the marls of unit 1 and the late Miocene age of these marls became more evident.

At the Fifth Congress on Mediterranean Neogene Stratigraphy (Lyon, September, 1971), Martini (1971b) demonstrated that the "caliza tosca" unit belongs to the Ceratolithus tricorniculatus Zone (nannofossil), ${ }^{11}$ but that the Discoaster quinqueramus Zone is present in Unit 1, which also includes the $D$. calcaris Zone, found in the type Tortonian. With this extended Andalusian, an overlap with the type Tortonian exists (see also Chapter 40).

The presence of a continuous, marine section straddling the Miocene/Pliocene boundary in an embayement of the Atlantic is not surprising. Bizon and Bizon (in Bizon, Bizon and Montenat, 1971) point out some "Atlantic" features observed in the foraminiferal assemblages of the Guadalquivir basin, including:

1) Occurrence in the terminal Miocene of Carmona of Globoquadrina altispira in abundance. This species is never recorded in sediments of this age in the Mediterranean, though it is recorded in the Lower Pliocene there;

2) Persistence of forms of the Globorotalia menardii group in the Pliocene, unlike in the Mediterranean;

3) Absence, in the terminal Miocene of Andalusia, of umbilico-convex, conical Globorotalia as G. mediterranea, G. conomiozea, etc., which appear to be limited to the late Miocene of the Mediterranean.

Points 1 and 2 have been discussed in Chapter 40 (differences between Atlantic and Mediterranean faunas) since observations similar to those made by the Bizons on

\footnotetext{
${ }^{11}$ Recorded in Mediterranean DSDP cores at the base of the Pliocene.
} 
the type Andalusian versus Mediterranean faunas have been done by us for the deep-sea North Atlantic versus deep-sea Mediterranean faunas.

We have no arguments in favor of observation 3 since our limited penetration in late Miocene sediments prevented the recovery of fossiliferous sediments of early Messinian age, where the mentioned taxa are usually recorded.

The occurrence of Andalusian outcrops in the area of southern Spain facing the Mediterranean (prov. Murcia and Alicante) appears questionable. In light of the desiccation model for the origin of the late Miocene (Messinian) evaporites of the Mediterranean (see Chapter 43, this volume), it is difficult to admit in southern Spain, facing the Mediterranean, continuous marine deposition, uninterrupted from the Tortonian to the Tabianian. However, the data presented by Montenat (in Bizon, Bizon and Montenat, 1971) do not exclude gaps in sedimentation since every marine invasion would carry in faunas of a single biozone. His section across the basin of Murcia-Alicante is in good agreement with our model. In fact, evaporites occur, with increasing thickness, toward the open sea, and they are overlain by marine deposits of early Pliocene age. The Pliocene is incomplete in its lower part, and unconformably overlies brackish-water sediments (marnes a Huitres) in the internal part of the basin.

Continental deposits are also recorded in the internal outcrops. At La Alberca, near Murcia, yellow sands interbedded in the "Marnes de Torremendo" yielded a Mammalian fauna referred by Montenat and Crusafont (1970) to the Vallesian (=fauna of Pikermi). The Torremendo marls are late Miocene in age and yield Globigerinoides obliquus extremus, Globorotalia humerosa, and others. The same situation found by De Brujin, Sondaar and Zachariasse (1971) in Crete seems to be repeated near Murcia, some $3000 \mathrm{~km}$ to the west.

The above discussion indicates that the time represented by the type Andalusian, as originally defined, corresponds in part to the Messinian (Unit 1, pro parte) and in part to the Tabianian (extreme top of Unit 1, and all of Unit 2 "caliza tosca"; see Bizon, Bizon, and Montenat, 1971; Verdenius, 1970).

The outcrops of Spain that belong to the AlicanteMurcia basins show lithologic and paleontologic features significantly different from those in outcrops on the Atlantic side at Guadalquivir. Thus the Andalusian is not a suitable chronostratigraphic unit for the Mediterranean area, and the utility of introducing a new geochronological subdivision for this interval appears very doubtful inasmuch as a stage that straddles an epoch boundary is considered unsuitable.

\section{ACKNOWLEDGMENTS}

The author is indebted to Consiglio Nazionale delle Ricerche of Italy (Comitato 05) for financial support.

She is grateful to Miss M. Zocchi, who is working on the statistics of the Globorotalia margaritae group, for her helpful assistance; to Walter Blow for providing topotypes of some taxa erected in 1969, including Globorotalia hirsuta praehirsuta; to Hans Bolli for providing samples from the type area of Globorotalia margaritae; to Isabella Premoli and Pedro Bermudez for providing samples from the type locality of Globorotalia margaritae; to Silvia Iaccarino for providing samples from the stratotype Tabianian; to Raffaele Scorziello for providing samples from the type locality of Globorotalia hirsuta praehirsuta.

Francesco Barbieri, Jean-Pierre Beckmann, William Berggren, Germain Bizon, Hans Bolli, David Bukry, Maria Adelaide Chierici, Neri Ciaranfi, Giuliano Mazzola, Vincenzo Palmieri, Enrico Perconig, Richard Olsson, Isabella Premoli, William Ryan, Umberto Salvatorini, Raffaele Sartoni, Tsuni Saito, Raffaele Sprovieri, and Herbert Stradner are acknowledged for discussing various aspects of Pliocene biostratigraphy.

The author is deeply indebted to F. Barbieri, R. Benson, W. A. Berggren, H. M. Bolli and to Professor H. Hedberg for their appreciated comments and constructive criticism regarding the present report.

\section{REFERENCES}

AGIP Mineraria, 1957. Foraminiferi padani (Terziario e Quaternario). Plates 1-52, Tip. Pezzini, Milano.

Barbieri, F., 1967. The foraminifera in the Pliocene section Vernasca-Castell'Arquato including the "Piacenzian stratotype" (Piacenza Province). Mem. Soc. Ital. Sc. Nat. 15 (3), 145.

, 1971a. Comments on some Pliocene stages and on the taxonomy of a few species of Globorotalia. Ateneo Parmense Acta Naturalia. 7 (1), 1. 1971b. Piacenzian. In Stratotypes of Mediterranean Neogene Stages. Giorn. Geol. 37 (2), 147.

Barbieri, F. and Selli, R., 1971. Tabianian. In Stratotypes of Mediterranean Neogene Stages. Giorn. Geol. 37 (2), 191.

Berggren, W. A. 1971. Multiple phylogenetic zonations of the Cenozoic based on planktonic foraminifera. Proc. II Plankt. Conference. 1, 41.

Bertolino, V. et al., 1968. Proposal for a biostratigraphy of the Neogene of Italy. CMNS Proc. IV Sess. Giorn. Geol. 35 (2), 23.

Bizon, G., 1967. Contribution à la connaissance des Foraminifères planctoniques d'Epire et des îles Ioniennes (Grèce occidentale). Publ. Inst. Franc. Pétrole Technip, Paris. 1.

Bizon, G., Bizon, J.J., and Montenat, C., 1971. Le Miocène terminal dans le Levant Espagnol (Provinces d'Alicante et de Murcia). CMNS Proc. V. Sess. 1 (preprint).

Blow, W. H., 1969. Late Middle Eocene to Recent planktonic foraminiferal biostratigraphy. Proc. I Intern. Conference Plankt. Microf. Ed. Brill. 1, 199.

Bolli, H. M., 1966a. Zonation of Cretaceous to Pliocene marine sediments based on planktonic foraminifera. $\mathrm{Bol}$. Inf. As. Ven. Geol., Min., Petr. 9 (1), 6.

, 1966b. The planktonic foraminifera in Well Bodjonegoro 1 of Java. Ecl. Geol. Helv. 59 (1), 449.

1970. The foraminifera of Sites 23-31, Leg 4. In Bader, R. G., Gerard, R. D., et al. (1970). Initial Reports of the Deep Sea Drilling Project, Volume IV. Washington (U. S. Government Printing Office). 577.

Bolli, H. M. and Bermudez, J. P., 1965. Zonation based on planktonic foraminiferida of Middle Miocene to Pliocene warm-water sediments. Bol. Inf. As. Ven. Geol. Min. Petr. 8 (5), 119.

Bronnimann, P., and Resig, J., 1971. A Neogene Globigerinacean biochronologic time-scale for the southwestern Pacific. In Winterer, E. L. et al. (1971). Initial Reports of the Deep Sea Drilling Project, Volume VII, Washington (U.S. Government Printing Office) 1235. 
Carloni, G. C. and Selli, R., 1971. Report of the discussions during the session on the stratotypes in Bologna. Giorn. Geol. 37 (2), 245.

Catalano, R., 1969. Tentativo di correlazione di due sondaggi nel Pliocene della Sicilia. Lavori Ist. Geol. Univ. Palermo. 7, 1 .

Cati, F., et al., 1968. Biostratigrafia del Neogene Mediterraneo basata sui foraminiferi planctonici. Boll. Soc. Geol. Ital. 87, 491 .

Cita, M. B., 1968. Report on the Working Group Micropaleontology. CMNS Proc. IV Sess. Giorn. Geol. 35 (2), 1. 1971. Biostratigraphy, Chronostratigraphy and Paleoenvironment of the Pliocene of Cape Verde (North Atlantic). Rev. Micropal. 14 (5), 17.

Cita, M. B. and Blow, W. H., 1969. The biostratigraphy of the Langhian, Serravallian and Tortonian stages in the type-sections in Italy. Riv. Ital. Paleont. 75 (3), 549.

Cita, M. B. and Ciaranfi, N., 1971. Evidence of climatic changes in the deep-sea Pliocene from the Mediterranean (JOIDES-DSDP Cores). CMNS, Proc. V Sess. (in press).

Colalongo, M. L., 1968. Cenozone a Foraminiferi ad Ostracodi nel Pliocene e basso Pleistocene della serie del Santerno e dell'Appennino romagnolo. CMNS Proc. IV Sess. Giorn. Geol. 35 (3), 29.

1970. Appunti biostratigrafici sul Messiniano. Giorn. Geol. 36 (2), 515.

Colalongo, M. L. and Sartoni, R., 1967. Globorotalia hirsuta aemiliana, nuova sottospecie cronologica del Pliocene in Italia. Giorn. Geol. 34 (1), 265.

Conato, V. and Follador, U., 1967. Globorotalia crotonensis e Globorotalia crassacrotonensis, nuove specie del Pliocene italiano. Boll. Soc. Geol. Ital. 86, 555.

Crescenti, U., 1971a. Osservasioni sul Pliocene degli Abruzzi settentrionali: la trasgressione del Pliocene medio e superiore. Boll. Soc. Geol. Ital. 90 (1), 3.

1971b. Sul limite Miocene-Pliocene in Italia. Geologica Romana. 9, 1.

De Brujin, H., Sondaar, P. J. and Zachariasse, J. W., 1971. Mammalia and foraminifera from the Neogene Kastellion Hill (Crete). A correlation of continental and marine biozones. Kon. Nederl. Ak. Wet. Amsterdam. 74 (5).

Dondi, L. and Papetti, I., 1968. Biostratigraphical zones of the Po Valley Pliocene. CMNS Proc. IV. Sess. Giorn. Geol. 35 (3), 63.

d'Onofrio, S., 1964. I Foraminiferi del Neostratotipo del Messiniano.Giorn. Geol. 32 (2), 409. 1968. Biostratigrafia del Pliocene e Pleistocene inferiore delle Marche. Giorn. Geol. 35 (e), 99.

Gartner, S., 1969. Correlation of Neogene planktonic foraminifer and calcareous nannofossil zones. Trans. Gulf Coast Ass. Geol. Soc. 19, 585.

Gradstein, F. M., 1971. Biometrical study of Pliocene Globorotalia. Proc. II Plankt. Conference. 2, 583.

Hays, J. D. and Berggren, W. A., 1971. Quaternary boundaries and correlations. Symposium on Micropaleontology of the Oceans, Cambridge. 669.

Hays, J. D., Saito, T., Opdyke, N. D. and Burckle, L. M., 1969. Pliocene-Pleistocene sediments of the Equatorial Pacific: their paleomagnetic, biostratigraphic and climatic record. Bull. Geol. Soc. Am. 80, 1481.

Hay, W. W., 1970. Calcareous nannofossils from cores recovered on Leg 4, DSDP. In Bader, R. G., Gerard, R. D., et al. (1970). Initial Reports of the Deep Sea Drilling Project, Volume IV. Washington (U.S. Government Printing Office). 455.

Hedberg, H. D. (Ed.), 1971. Preliminary report on biostratigraphic units. IUGS Commission on Stratigraphy, International Subcommission on Stratigraphic Classification, Circular No. 36. 1.
Iaccarino, S., 1967. Les foraminifères du stratotype du Tabianien (Pliocène inférieur) de Tabiano Bagni (Parme). Mem. Soc. Ital. Sc. Nat. 15 (3), 165.

Lindenberg, H. G., 1969. Statistical notes on the variability of Globigerina eocaena Gümbel 1868 from the Paleogene of the Bavarian Alps. Proc. I Intern. Conf. Plankt. Organisms. Ed. Brill, 2, 343.

Mansour, A. T., Barakat, M. G., el S. Abdel and Hady, Y., 1969. Marine Pliocene planktonic foraminiferal zonation southeast of Selum, Egypt. Riv. Ital. Paleont. 75 (4), 833.

Martini, E., 1971a. Standard Tertiary and Quaternary calcareous nannoplankton zonation. Proc. II Plankt. Conference. 2, 739.

1971b. Calcareous nannoplankton from the type-Andalusian. CMNS, Proc. V Sess. 1 (preprint).

Martini, E. and Worsley, T., 1970. Standard Neogene calcareous nannoplankton zonation. Nature. 225 (5229), 289.

1971. Tertiary calcareous nannoplankton from the Western Equatorial Pacific. In Winterer, E. L., Riedel, W. R., et al. (1971). The Initial Reports of the Deep Sea Drilling Project, Volume VII. Washington (U. S. Government Printing Office). 1471.

Mazzola, G., 1971. Les Foraminifères planctoniques du Mio-Pliocène de l'Algérie Nord-occidentale. Proc. $I$ Plankt. Conf. 2. 787.

Montenat, C. and Crusafont, Peiro Mr., 1970. Découverte de Mammifères dans le Néogène et le Pléistocène du Levant espagnol (Provinces d'Alicante et de Murcia). C. R. Ac. Sc. 270, 234.

Ogniben, L., 1969. Schema introduttivo alla geologia del confine calabro-lucano. Mem. Soc. Geol. Ital. 8, 453.

Parker, F. L., 1967. Late Tertiary biostratigraphy (planktonic foraminifera) of tropical Indo-Pacific deep-sea cores. Bull. Am. Paleont. 52 (235), 115.

Perconig, E., 1966. Sull 'esistenza del Miocene superiore in facies marine nella Spagna meridionale. CMNS Proc. III Sess. Ed. Brill. 288.

1968a. Biostratigrafia della sezione di Carmona (Andalusia, Spagna) in base ai Foraminiferi planctonici. CMNS Proc. IV Sess. Giorn. Geol. 35 (3), 191.

1968b. Nuove specie di Foraminiferi planctonici della sezione di Carmona (Andalusia, Spagna). Ibidem, 233.

Roda, C., 1971. Zanclean. In Stratotypes of Mediterranean Neogene Stages. Giorn. Geol. 37 (2), 237.

Ruggieri, G., 1960. Segnalazione di Globoquadrina altispira nei trubi di Buonfornello (Palermo). Riv. Miner. Sicil. 11 (61), 3

Ruggieri, G., Catalano, R. and Sprovieri, R., 1968. Considerazioni sulla distribuzione del genere Globorotalia nel Pliocene siciliano. Boll. Soc. Geol. Ital. 87 (2), 277.

Ruggieri, G. and Selli, R., 1948. Il Pliocene ed il Postpliocene dell'Emilia. Giorn. Geol. 20, 1.

Sampò, Mr., Zappi, L. and Caretto, P. G., 1968. Les Foraminifères de l'Astien. CMNS Proc. IV Sess. Giorn. Geol. 35 (3), 277.

Seguenza, G., 1868. La formation zancléenne, ou recherches sur une nouvelle formation tertiaire. Bull. Soc. Géol. France. 2 (25), 465.

Scott, G. H., 1968. Globigerinoides in the AquitanianBurdigalian of SW France. CMNS Proc. IV Sess. Giorn. Geol. 35 (2), 271.

Selli, R., 1960. Il Messiniano Mayer-Eymar. Proposta di un neostratotipo. Giorn. Geol. 28, 1.

Verdenius, J. G., 1970. Neogene stratigraphy of the western Guadalquivir basin (Southern Spain). Utr. Micropal. Bull. 3, 1. 


\section{PLATE 1}

Globorotalia margaritae evoluta n. subsp. Lower Pliocene of the Tyrrhenian Basin, Globorotalia margaritae evoluta Lineage-zone, immediately below the Globorotalia margaritae evoluta extinction horizon. Sample: DSDP 13-132-14, CC.

Figure 1 Spiral view of the holotype; $\times 150$. A distinct imperforate keel is visible in the three last-formed chambers. Buttresses are limited to the early onthogenetic stage.

Figure 2 Spiral view of a large, flat specimen with a fairly thick imperforate keel in the ultimate and penultimate chambers; $\times 150$.

Figure 3 Umbilical view of a specimen with an abortive final chamber, a rather common feature of the latest evolutionary stages of $G$. margaritae. The umbilicus is narrow and distinct; the intercameral sutures are depressed and gently curved (almost radial), the slit-like umbilical-extraumbilical aperture shows an extended lip; $\times 75$.

Figure 4 Side view (opposite to the apertural face) of a large specimen, showing a distinct imperforate keel in the last three chambers, the smooth and highly perforated surface of the chamber walls in the last whorl, and the obliterated and pitted initial whorls; $\times 150$.

Figure 5 Spiral view of a specimen with an abortive final chamber, which shows a smoother and less perforated wall than the preceding chambers of the last whorl; X153.

Figure 6 Spiral view of a specimen transitional to Globorotalia margaritae margaritac; the equatorial periphery is slightly more elongated than in the specimens illustrated in Figures 1, 2, 5. The imperforate keel is visible in the ultimate and penultimate chambers. Buttresses are not limited to the initial whorls, but are frequent (though smaller) also in the penultimate chamber (see Figure 7); $\times 153$.

Figure 7 Detail of the surface of the penultimate chamber of the specimen shown in Figure 6; $\times 850$.

All the specimens illustrated in this plate, as well as in the following ones, are deposited in the Collection of the Laboratory of Micropaleontology, University of Milano. Photographs SEM by G. Gabriele (Institute of Geology, University of Milano). 
PLATE 1

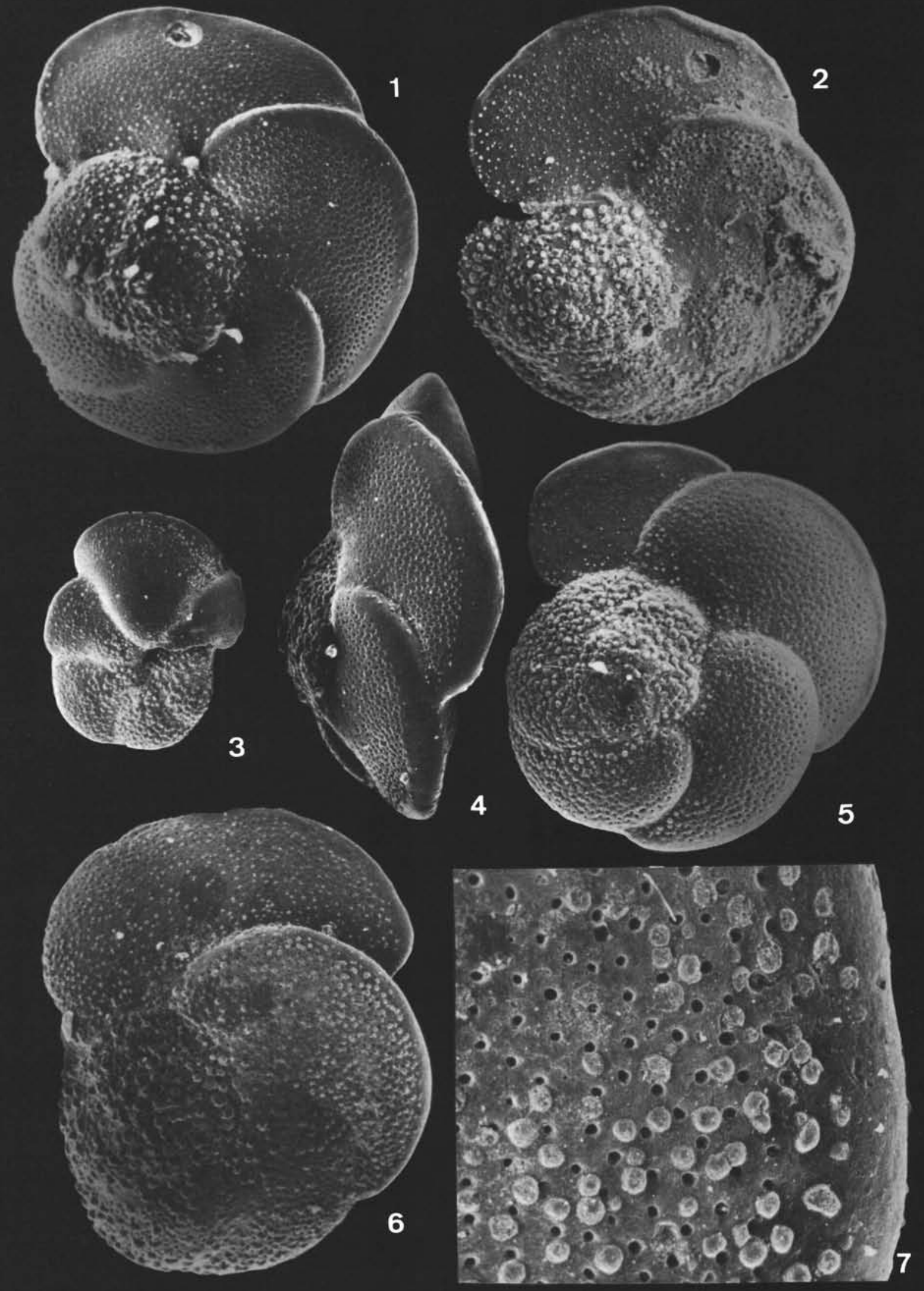




\section{PLATE 2}

All the specimens are from Sample DSDP 13-132-14, CC.

Lower Pliocene of the Tyrrhenian Basin, Globorotalia margaritae evoluta

\section{Lineage-zone}

Figures 1-3 Globorotalia margaritae primitiva n. subsp.

1. Spiral view of a specimen showing the absence of a distinct imperforate keel, little lobulated periphery and small size of the test; $\times 160$.

2. Umbilical view of the holotype, showing the slightly lobulated, subcircular equatorial periphery, slightly depressed radial sutures, fairly large and deep umbilicus, and slit-like umbilical-extraumbilical aperture, with a thin lip; $\times 157$.

3. Apertural view of the holotype, showing the subacute periphery, slightly inflated chambers, spinose chamber walls; $\times 160$.

Figures 4-6 Globorotalia margaritaemargaritae Bolli and Bermudez.

4. Spiral view of a specimen showing a rapid increase of the chamber height in the last whorl, a distinct imperforate keel in the last and penultimate chambers, and a fairly elevated, eccentric spire; $\times 157$.

5 . Spiral view of a typical specimen; $\times 165$.

6. Umbilical view of a typical specimen, showing how the width of the last chamber may be greater than the equatorial diameter $\mathrm{A}-\mathrm{A}^{\prime} ; \times 157$. 


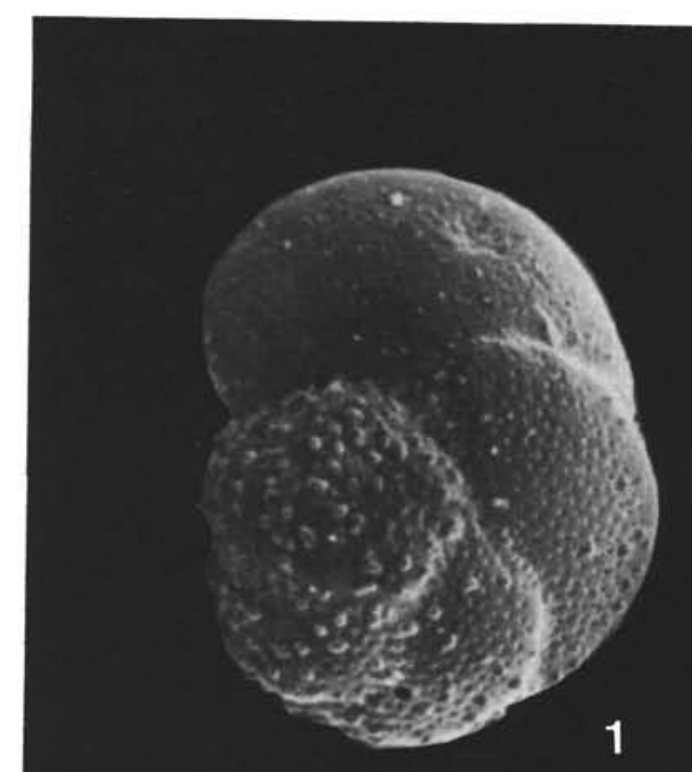

\section{PLATE 2}

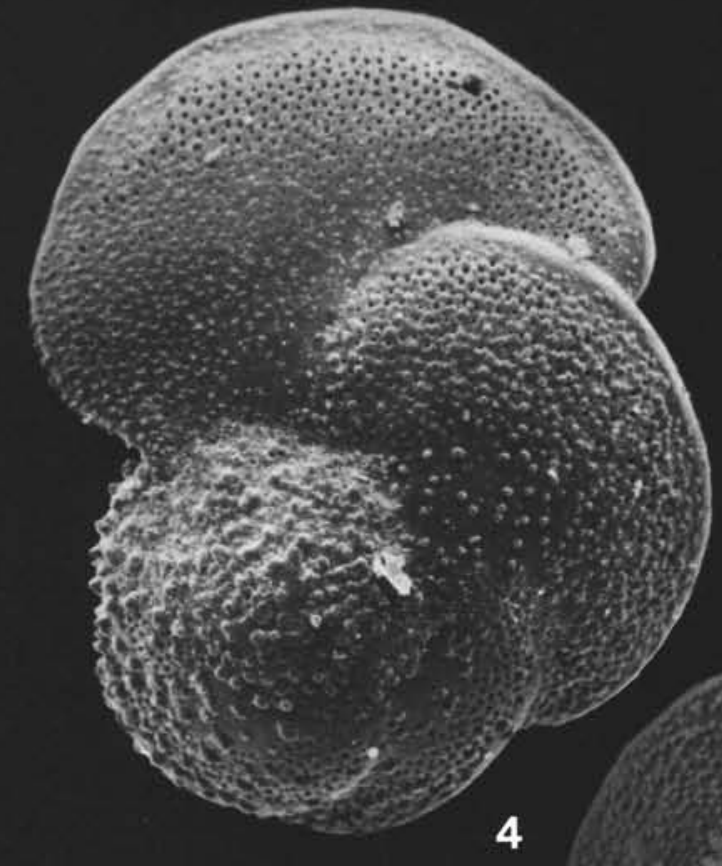

2
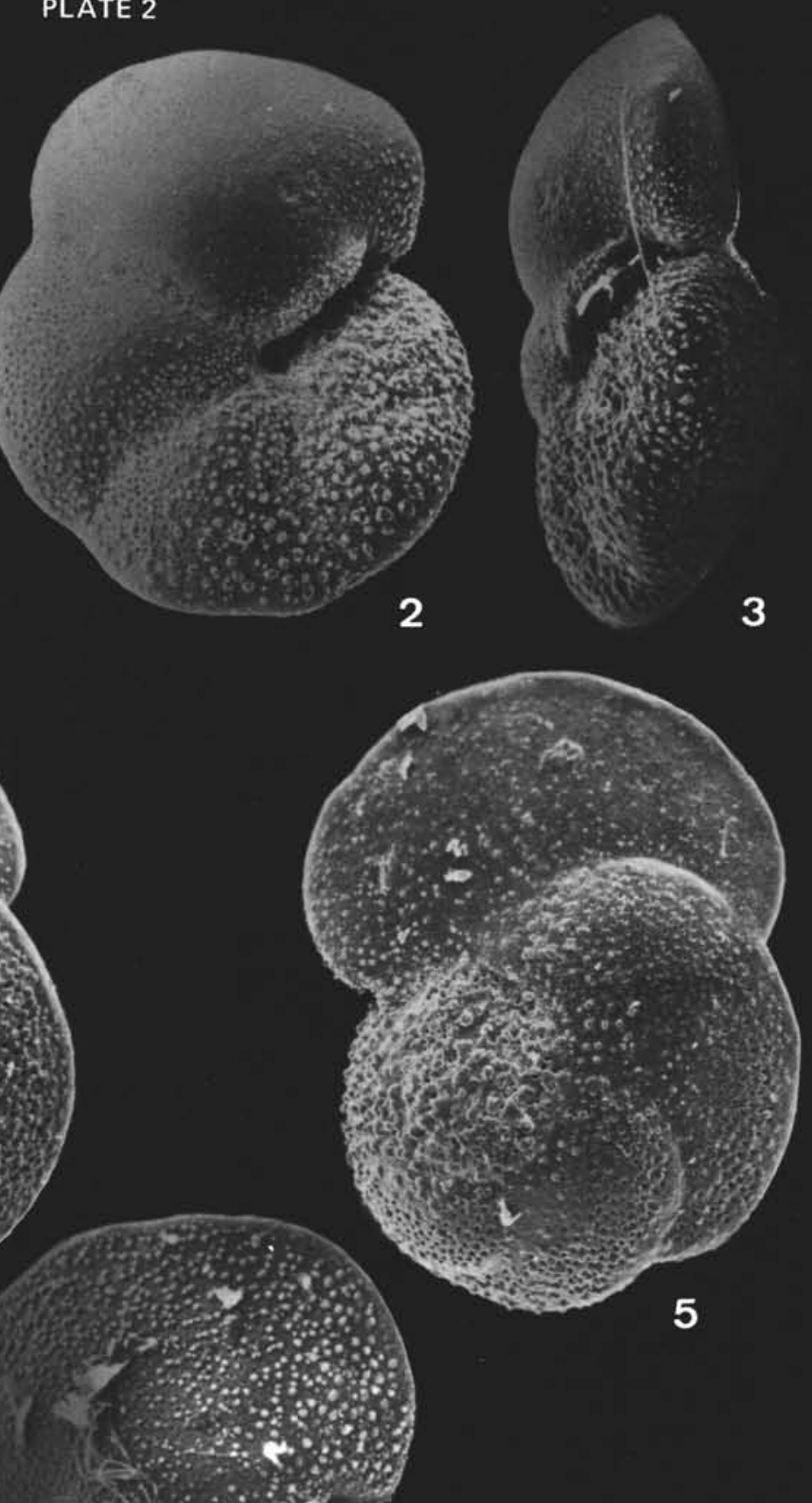

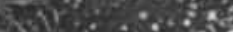

(30)

intives:

(i) 3 in

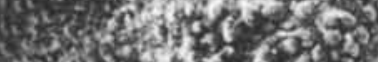

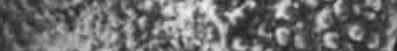

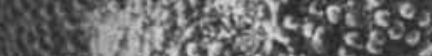

303 ing int

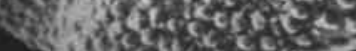


PLATE 3

Globorotalia puncticulata (Deshayes). Sample DSDP 13-132-14, CC. Lower Pliocene of the Tyrrhenian Basin, Globorotalia margaritae evoluta Lineage-zone, immediately prior to the extinction horizon of Globorotalia margaritae (group).

Figure 1 Spiral view of a large, typical specimen, $X 153$.

Figure 2 Spiral view of a small specimen; $\times 153$.

Figure 3 Umbilical view, showing the large umbilical-extraumbilical aperture, with a thin but distinct rim. The last-formed chamber has smaller pores than the preceding ones, and its surface is smoother; $\times 165$.

Figure 4 Side view, slightly oblique; $\times 185$.

Figure 5 Umbilical view of a small specimen; $\times 135$.

Figure 6 Side view of a small specimen, showing a highly pitted surface and wide aperture, surrounded by a distinct rim; $\times 153$. 


\section{PLATE 3}
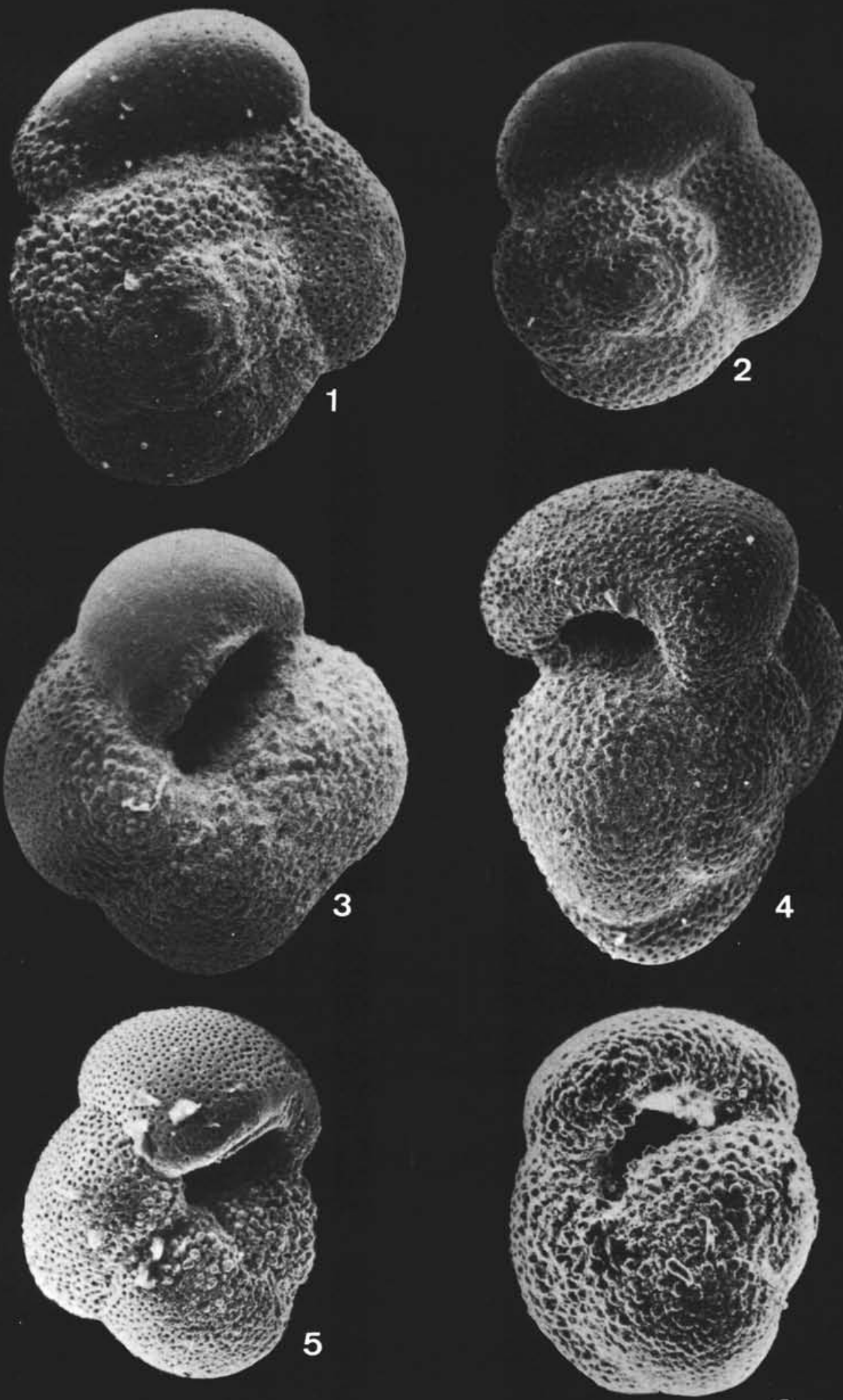
PLATE 4

Figures 1-6 Globorotalia crassaformis (Galloway and Wissler). Sample: DSDP 134E, SWC 1, Upper Pliocene of the Balearic Basin, Globigerinoides obliquus extremus Interval-zone.

1. Spiral view of a specimen with four chambers in the last whorl; the last formed chamber has an acute periphery, however no imperforate keel is visible; $\times 135$.

2. Spiral view of a large specimen with five chambers in the last whorl and an abortive final chamber. Subacute periphery, no peripheral keel; $\times 120$.

3. Spiral view of a large specimen with $4-1 / 2$ chambers in the last whorl and subacute periphery; $\times 120$.

4. Umbilical view of a typical specimen, showing the fairly large umbilicus, conical shape of the chambers; depressed, radial sutures; $\times 170$.

5. A detail of Figure 4, showing the evenly spaced pores and pronounced buttresses. A number of coccoliths are visible, on the right; $\times 1530$.

6. A detail of Figure 4, showing the umbilicalextraumbilical aperture, with a faint apertural lip; $\times 390$.

Figure $7 \quad$ Globorotalia scitula (Brady). Umbilical view of a right-coiling specimen, showing a smooth surface of the chambers, rare and evenly spaced pores, gently curved and depressed intercameral sutures, wide and flat umbilicus, slit-like umbilical-extraumbilical aperture, with a distinct apertural lip; $\times 170$. Sample: DSDP 13-132-14, CC. Lower Pliocene of the Tyrrhenian Basin. Globorotalia margaritae evoluta Lineage-zone. 
PLATE 4
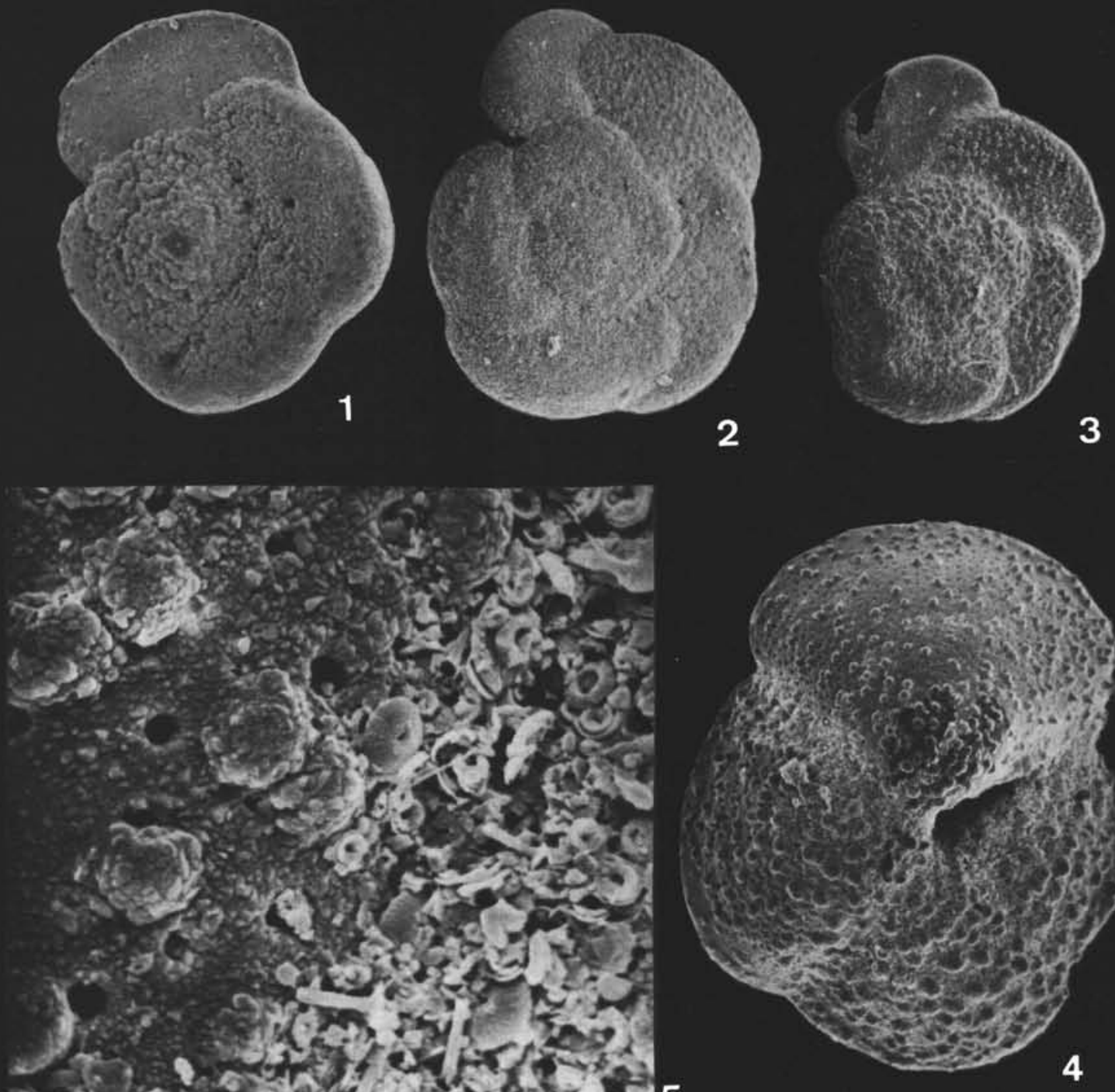

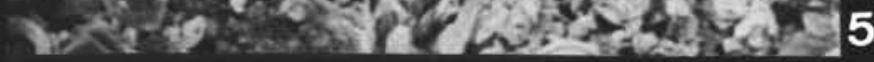
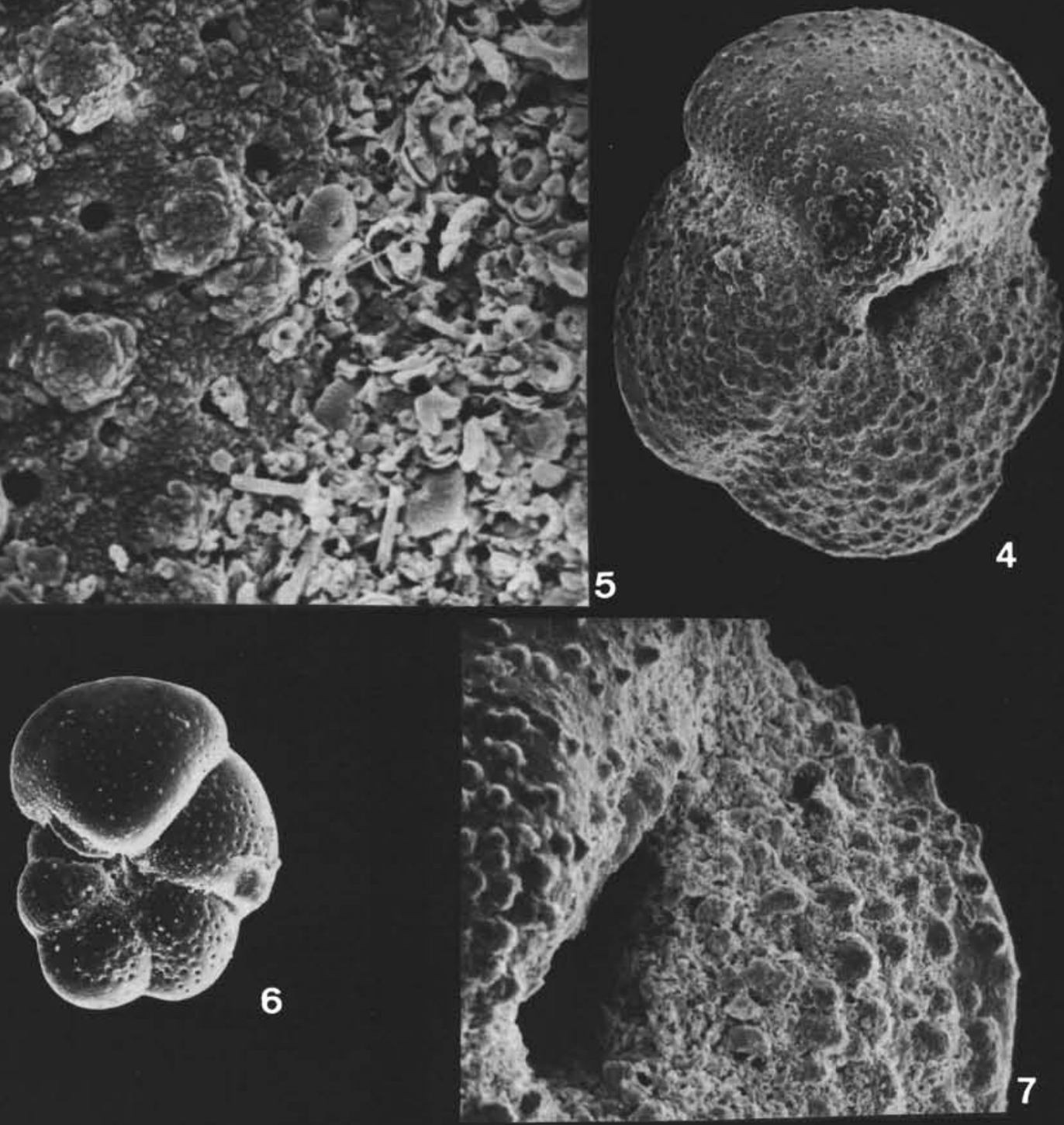


\section{PLATE 5}

All figures $\times 128$. In all figures $a=$ spiral view; $b=$ side view; $\mathrm{c}=$ umbilical view. Camera lucida drawings by

J. van den Linden, Utrecht.

Figure 1 (a-c) Globorotalia crassaformis viola Blow. Upper Pliocene, Sphaeroidinellopsis subdehiscens Interval-zone of the Tyrrhenian Basin. Sample: DSDP 13-132-11, CC.

Figure $2(\mathrm{a}-\mathrm{c}) \quad$ Globorotalia aemiliana Colalongo and Sartoni. Upper Pliocene, Sphaeroidinellopsis subdehiscens Intervalzone of the Tyrrhenian Basin. Sample: DSDP 13132-11, CC.

Figure 3 (a-c) Globorotalia menardii (d'Orbigny). Upper Pliocene, Sphaeroidinellopsis subdehiscens Interval-zone of the Ionian Basin. Sample: DSDP 125A-5-1, 108-110 cm. 

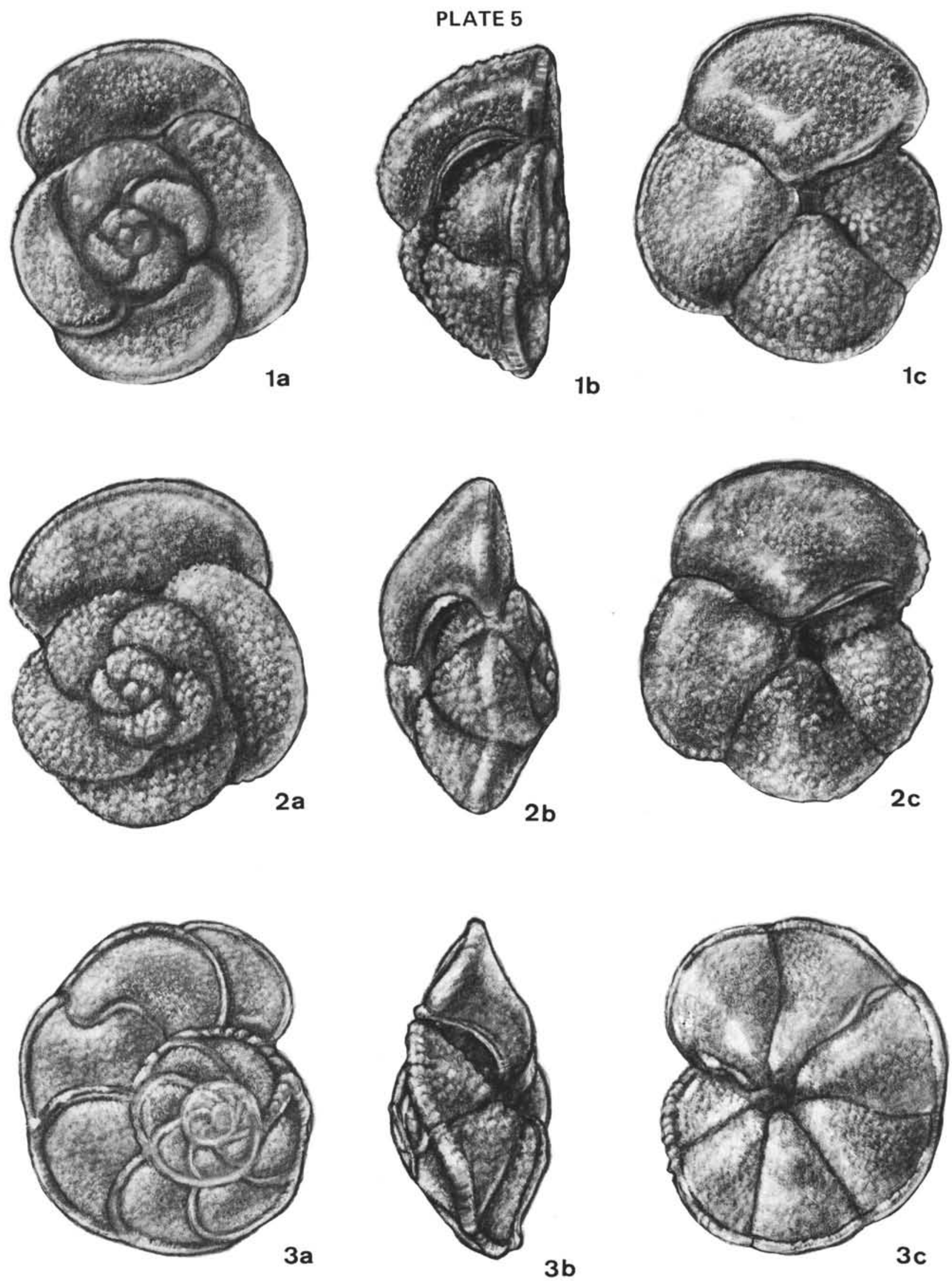

0

250

$500 \mu$ 


\section{PLATE 6}

All specimens illustrated are from Sample DSDP 13-132-21-1, 60-62 $\mathrm{cm}$. Lowermost Pliocene of the Tyrrhenian Basin, Sphaeroidinellopsis Acme-zone. This level lies some $165 \mathrm{~cm}$ above the Miocene/Pliocene boundary (see Figure 2, this Chapter) and can be identified with the Sphaeroidinella-datum.

Figure 1 Sphaeroidinellopsis subdehiscens Blow. Umbilical view; $\times 115$.

Figure 2 A detail of Figure 1, showing the primary aperture with an enclosed unidentified planktonic foraminifer; $\times 435$.

Figure $3 \quad$ Sphaeroidinellopsis seminulina (Koch). Spiral view; $\times 185$.

Figure 4 Detail of Figure 3, showing the heavily calcified cortex; $\times 425$.

Figure 5 Sphaeroidinella dehiscens immatura Blow; $\times 160$. Spiral view of a specimen showing incipient supplementary apertures on both sides.

Figure $6 \quad$ Sphaeroidinellopsis seminulina (Koch). Spiral view; $\times 160$.

Figure $7 \quad$ Sphaeroidinellopsis subdehiscens Blow. Umbilical view of a specimen with a very large primary aperture; $\times 75$. 


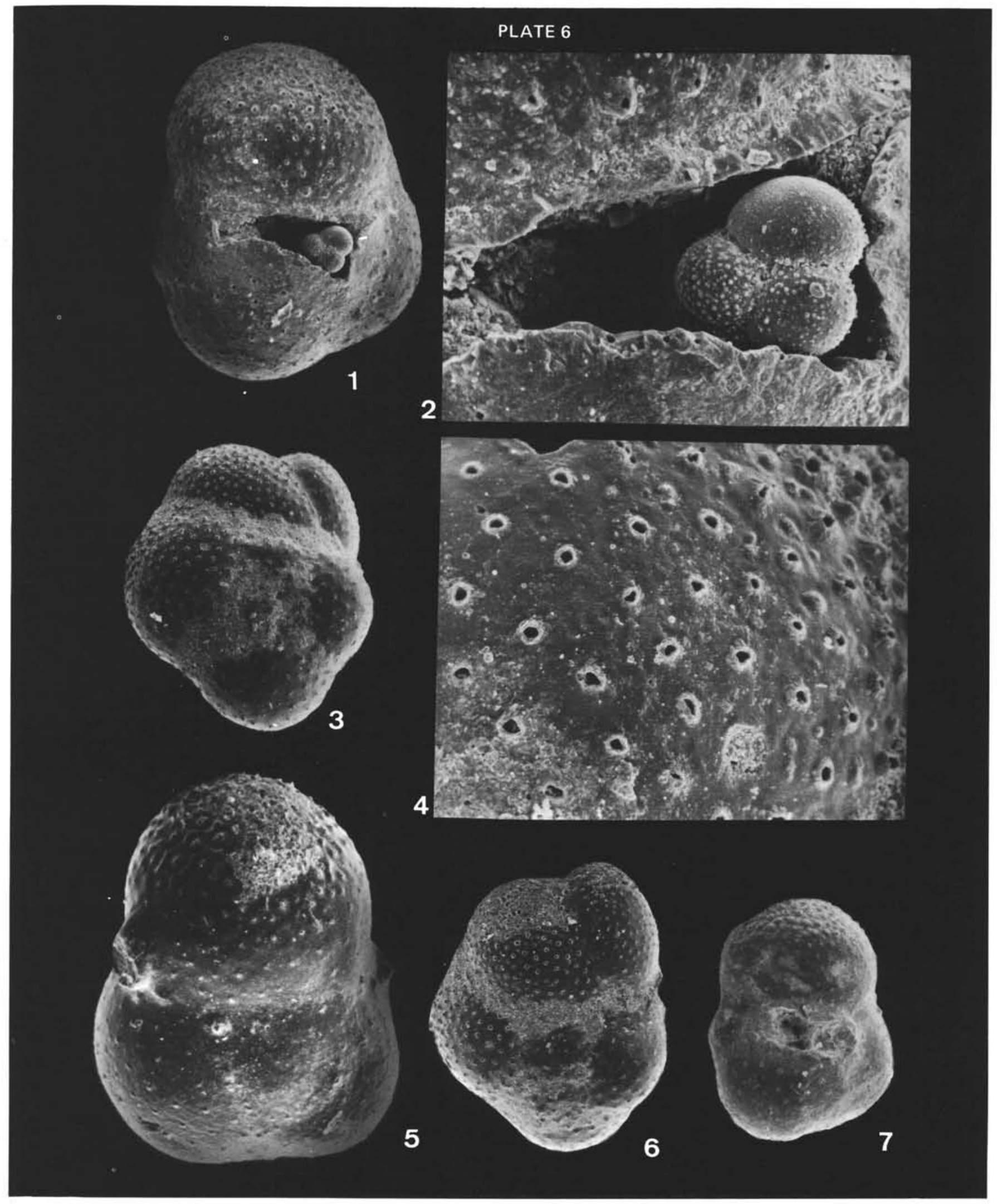




\section{PLATE 7}

Figure 1

Figure 2

Figure 3

Figure 4

Figure 5
Globigerinoides sacculifer (Brady). Spiral view; $X 115$. Sample: DSDP 13-132-14, CC. Lower Pliocene of the Tyrrhenian Basin. Globorotalia margaritae evoluta Lineage-zone.

Globigerinoides obliquus extremus Bolli. Umbilical view, passing to side-view; $\times 153$. Sample DSDP 13-134E-SWC1. Upper Pliocene of the Balearic Basin.

Globigerinoides obliquus extremus Interval-zone.

A detail of Figure 2, showing the cancellated surface, with funnel-shaped cavities and opened pores. Coccoliths are visible on the test surface; $\times 765$.

Globigerinoides conglobatus (Brady). Side view; $\times 75$. Sample: DSDP 13-134E-SWC1. Upper Pliocene of the Balearic Basin. Globigerinoides obliquus extremus Interval-zone.

A detail of Figure 4, showing thick, heavily calcified wall and well-spaced, mostly filled pores; $\times 765$. 


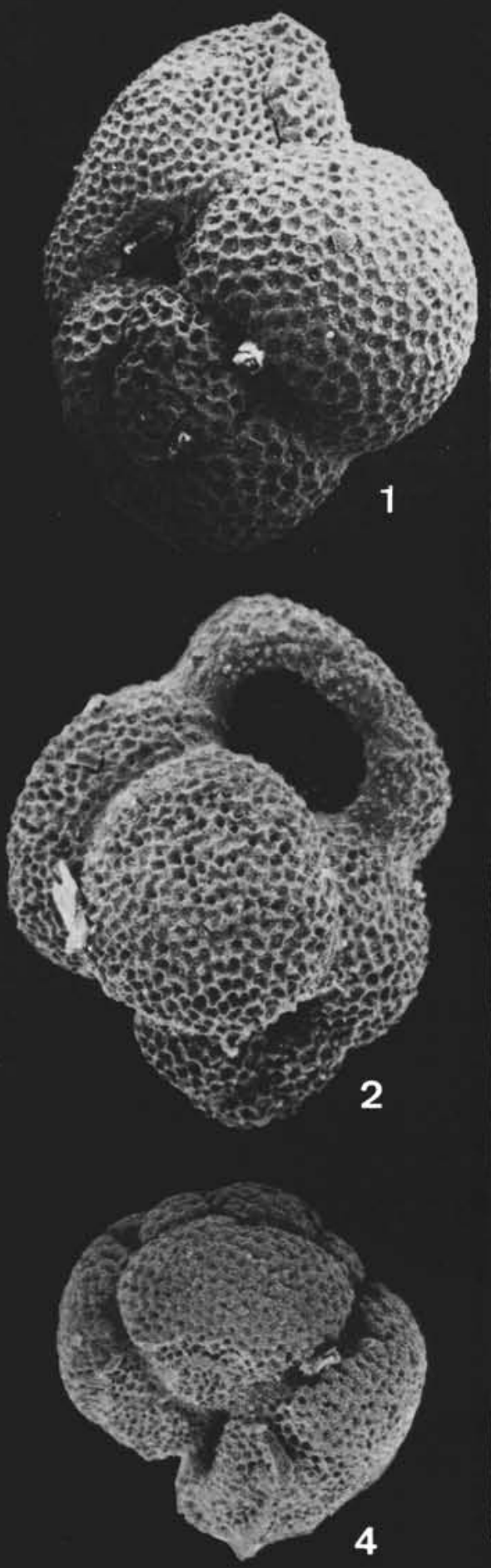

PLATE 7
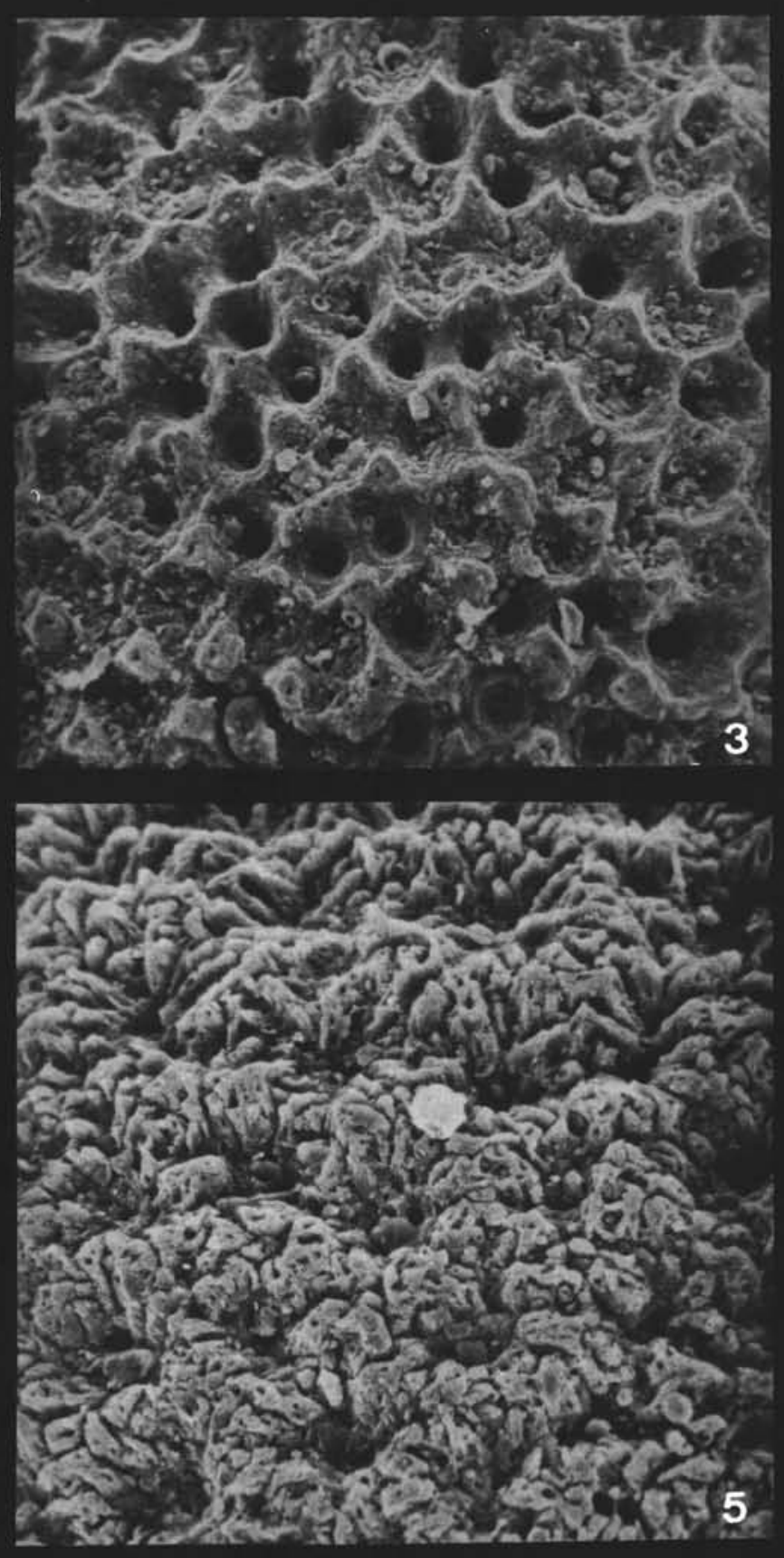